FRANCISCO DE ASSIS PRADO GALHANO

\title{
Petróleo e Gás na Bacia do Paraná
}

Tese apresentada à Escola Politécnica da

Universidade de São Paulo para obtenção do

Título de Doutor em Engenharia. 


\title{
FRANCISCO DE ASSIS PRADO GALHANO
}

\section{Petróleo e Gás na Bacia do Paraná}

\author{
Tese apresentada à Escola Politécnica da \\ Universidade de São Paulo para obtenção do \\ Título de Doutor em Engenharia.
}

Área de Concentração: Engenharia Mineral.

ORIENTADOR: Prof. Titular Wildor Theodoro Hennies. 


\section{FICHA CATALOGRÁFICA}

\section{Galhano, Francisco de Assis Prado}

Petróleo e Gás na Bacia do Paraná / F. de A. P. Galhano. -São Paulo, 2006.

$108 \mathrm{p}$.

Tese (Doutorado) - Escola Politécnica da Universidade de São Paulo. Departamento de Engenharia de Minas e de Petróleo.

1.Petróleo - Bacia do Paraná 2.Perfuração (Métodos) I.Universidade de São Paulo. Escola Politécnica. Departamento de Engenharia de Minas e de Petróleo II.t. 
Aos meus queridos pais Antonio Prado Galhano e Alice Medeiros Galhano, que diante de Deus estão celebrando este momento. 


\section{DEDICATÓRIA}

Dedico este trabalho à minha amada esposa Rosa Maria, aos meus queridos filhos, Francisco Carlos, Maria Elisa, Fernando Cesar, Andréa Maria e Flávio Celso, e aos meus adoráveis netos Francisco Carlos Junior, Gabriel Antonio e Henrique, pelo incentivo que me deram. 


\section{AGRADECIMENTOS}

Agradeço o incentivo de meus caríssimos irmãos Maria Alice, Marília, José Hamilton, Maria Auxiliadora, João Bosco, Ana Maria, Nair Helena e Maria de Fátima.

Agradeço também a tantos amigos pela ajuda e incentivo, em especial:

Prof. Titular Carlos Celso do Amaral e Silva, Prof. Dr. Lindolfo Soares, Prof. Dr. Pedro Caetano Sanches Mancuso, Prof. Dr. Riuiti Yoshida, Doutor. Carlos Tadeu Lauand, Doutorando Alberto de Barros Aguirre, Doutoranda Valena Hennies Lauand, $\mathrm{Eng}^{\circ}$ José Roberto Camargo Monteiro, Eng ${ }^{\circ}$ Edson Curi Kachan, Geofísico Roberto Breves Vianna, Geólogo Júlio de Arruda Bruno, Eng ${ }^{\circ}$ João de Araújo, Prof. João Teodoro da Silva, Sr. Tiago Aguirre e a Supervisora da Biblioteca do Departamento de Engenharia de Minas e de Petróleo da EPUSP, Srta. Maria Cristina Martinez Bonesio.

E um agradecimento especial ao meu orientador, Prof. Titular Wildor Theodoro Hennies, homem sábio, experiente, de extrema bondade e educador por excelência. 


\section{RESUMO}

Uma vez definidos os objetivos da tese e estabelecida a metodologia de sua elaboração, passou-se ao trabalho, com a síntese histórica da pesquisa de petróleo.

Foi introduzido um capítulo de comentários sobre as crises do petróleo de 1973 e 1979.

Descreveu-se a criação do Consórcio CESP/IPT, as suas finalidades, a sua constituição, as definições de responsabilidades da CESP e do IPT e os contratos assinados com a Petróleo Brasileiro S/A - PETROBRÁS.

Mostrou-se a atuação da PETROBRÁS na Bacia do Paraná, desde a fundação da empresa em 1953 até 1974.

Quanto aos trabalhos executados pelo Consórcio CESP/IPT no período de 1980,1981 e 1982, o Quadro 1 apresenta os dados geológicos adquiridos no referido período.

Os resultados da sísmica de reflexão demonstraram a sua viabilidade mudando o conceito antigo de baixa resolução na Bacia do Paraná.

As análises de geoquímica se concentraram principalmente nas Formações Ponta Grossa e Irati.

A engenharia de perfuração do Consórcio CESP/IPT perfurou 32 poços, sem perda nem interrupção de nenhum deles, numa bacia complexa como a do Paraná.

O programa de brocas otimizou o resultado das perfurações.

Foi testada e aprovada a utilização da perfuração a ar, pioneira na referida bacia, para aplicação nas formações duras, como o basalto e 0 diabásio. 
Os Serviços Associados à Perfuração de Poços consideraram o Programa de Brocas e a Perfilagem e Testes de Formação.

Por fim, o trabalho incluiu o relatório do Poço de Cuiabá Paulista.

$\mathrm{Na}$ conclusão, procurou-se mostrar que os propósitos dos objetivos foram alcançados. 


\section{ABSTRACT}

Once defined the thesis objectives and established its methodology, the work has begun, with an historical research of petroleum.

A chapter about the petroleum crises in 1973 and 1979 was introduced.

The foundation of CESP/IPT enterprise, its objectives, constitution, responsibilities and contracts signed with PETROBRAS were described.

The work of PETROBRAS at Parana's Basin, since PETROBRAS Foundation in 1953 through 1974, was showed.

The picture 1 presents geological data of the work done by the enterprise, in the period of $1980,81,82$.

The seismic reflection results show Parana Basin's viability, changing the old concept of low solution at this area.

The geochemical analysis was done mainly in Ponta Grossa and Irati Formations.

The drill engineering of the enterprise drilled 32 wells, without damaging or interrupting anyone, in a complex basin like Parana's.

The Drill Bit Program provided more efficiency in drilling. Air Drilling was tested and approved, first of all at Parana's basin, to be used in solid formation like basalt and diabase.

The Well Program Associated Services considered the Bit Program, the Well Logging and Formation Tests.

Finally, the job included a Cuiaba Paulista Well's report.

At the conclusion, it was showed that the objectives were achieved. 


\section{SUMÁRIO}

Página

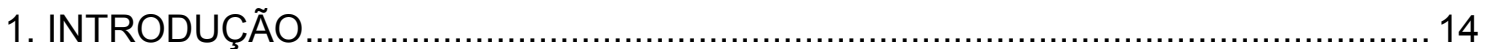

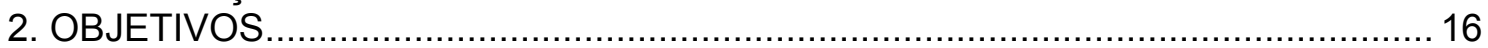

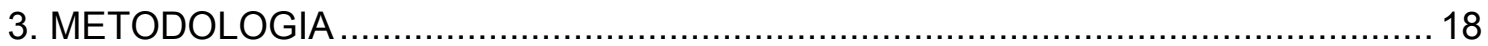

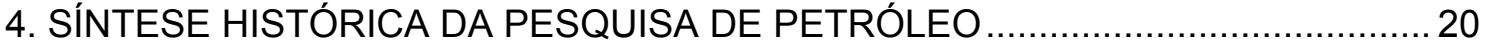

5. COMENTÁRIOS SOBRE AS CRISES DO PETRÓLEO DE 1973 E DE 1979.........23

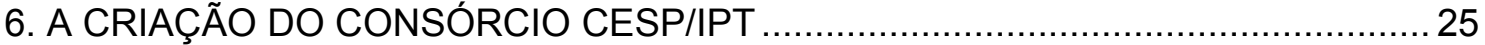

6.1 A BACIA GEOLÓGICA DO PARANÁ ....................................................... 28

7. ATUAÇAO DA PETROBRÁS DE 1953 A 1974 NA BACIA DO PARANÁ................... 30

8. TRABALHOS EXECUTADOS PELO CONSÓRCIO CESP/IPT NA BACIA DO

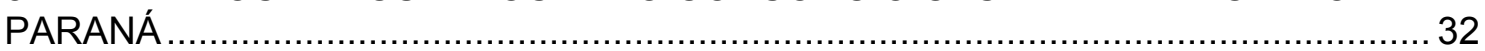

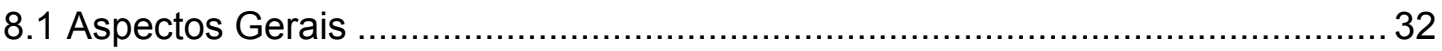

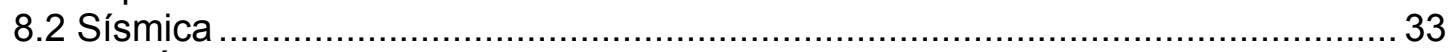

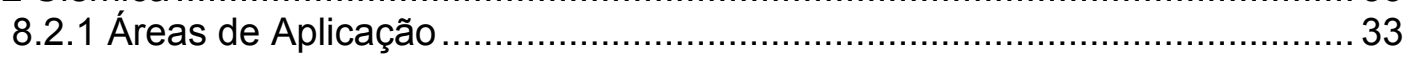

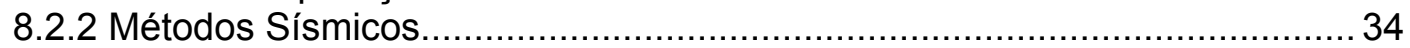

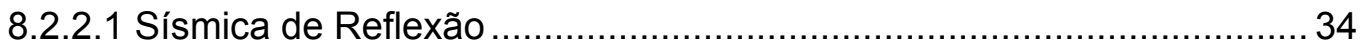

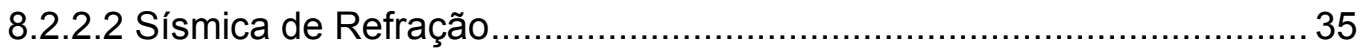

8.2.3 Sísmica de Reflexão na Bacia do Paraná ................................................. 35

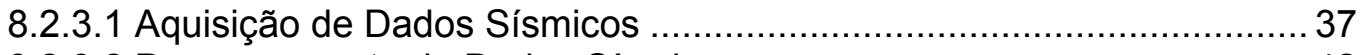

8.2.3.2 Processamento de Dados Sísmicos .............................................. 42

8.3 Geoquímica da Bacia do Paraná ................................................................ 47

8.3.1 Geoquímica das Formações - Ponta Grossa e Irati na Bacia do Paraná ... 47

8.4 Engenharia de Perfuração na Bacia do Paraná ................................................51

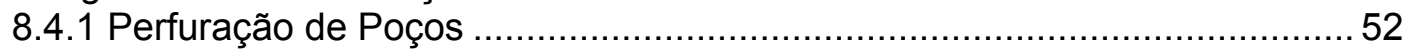

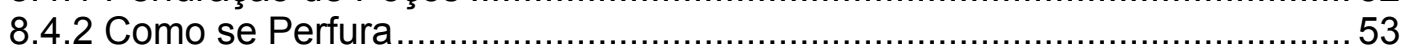

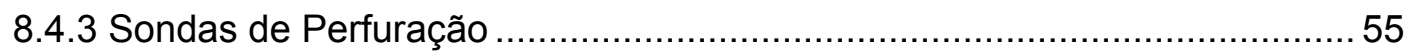

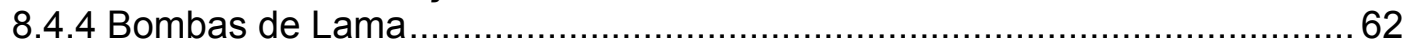

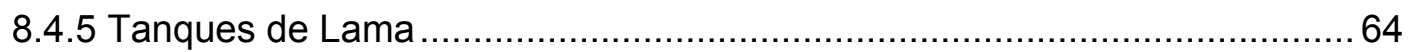

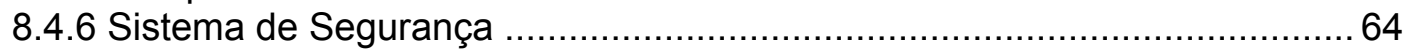

8.4.7 Sistemas de Monitoramento de Perfuração de Poços....................................6 65

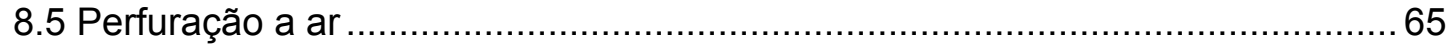

8.6 Serviços Associados à Perfuração de Poços ..................................................... 66

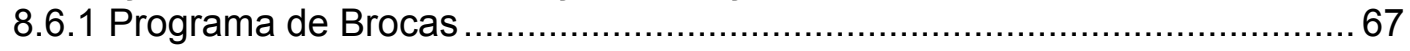

8.6.2 Perfilagem e Testes de Formações ........................................................ 74

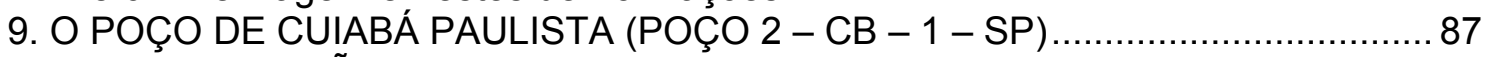

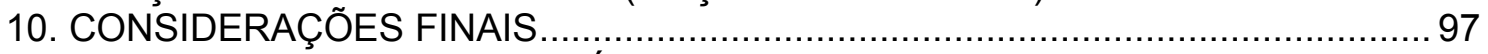

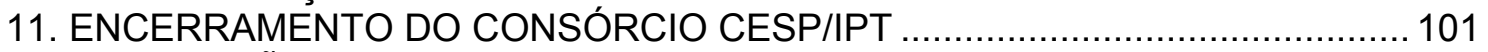

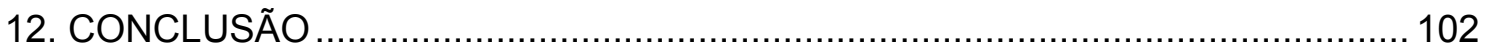

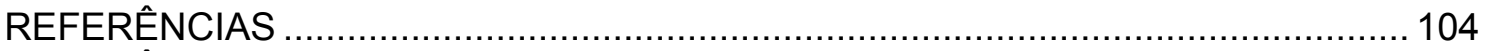

REFERÊNCIAS COMPLEMENTARES 


\section{LISTA DE FIGURAS}

Figura 01 - Localização Esquemática dos blocos do Consórcio CESP/IPT, com indicação do Programa de Poços Estratigráficos e Pioneiros

Figura 02 - Mapa Esquemático da Bacia Sedimentar do Paraná

Figura 03 - Mapa Esquemático de Localização das Equipes Sísmicas

Figura 04 - Vista de uma Equipe de Sísmica de Reflexão no campo

Figura 05 - Prospecto de seção de Linha Sísmica passando pelo Poço 2-CB-1Cuiabá Paulista - SP

Figura 06 - Prospecto de seção de Linha Sísmica na área de Rio Vorá - PR

Figura 07 - Componentes de uma Sonda de Perfuração de Petróleo

Figura 08 - Vista Geral da Sonda de perfuração no Poço de Taciba - SP

Figura 09 - Coluna Estratigráfica da Bacia do Paraná

Figura 10 - Vista do depósito de brocas de perfuração e de tubos de revestimentos, do Consórcio CESP/IPT em Bauru - SP

Figura 11 - Brocas de perfuração de petróleo

Figura 12 - Esquema de uma operação de perfilagem

Figura 13 - Esquema de "Mud Logging"

Figura 14 - Esquema de um Teste de Formação

Figura 15 - Carta de Pressão de um Teste de Formação por Coluna

Figura 16 - Mapa Esquemático de Situação do Poço 2-CB-1 - Cuiabá Paulista $\mathrm{SP}$

Figura 17 - Mapa Esquemático de Localização e Acesso do Poço 2-CB-1 Cuiabá Paulista - SP

Figura 18 - Litoestratigráfia constatada no Poço 2-CB-1 - Cuiabá Paulista - SP

Figura 19 - Esquema de perfuração do Poço 2-CB-1 - Cuiabá Paulista - SP

Figura 20 - Posicionamento esquemático dos testes do Poço 2-CB-1 - Cuiabá Paulista - SP

Figura 21 - Teste de formação do Poço 2-CB-1 - Cuiabá Paulista - SP 


\section{LISTA DE QUADROS}

Quadro 1 - Atividades desenvolvidas pelo Consórcio CESP/IPT.

Quadro 2 - Poços considerados na avaliação geoquímica pelo Consórcio CESP/IPT

Quadro 3 - Poços do Consórcio CESP/IPT que Produziram Gás Natural 


\section{LISTA DE ABREVIATURAS E SIGLAS}

CA - Cândido de Abreu

CB - Cuiabá Paulista

CENPES - Centro de Pesquisas e Desenvolvimento

CESP - Companhia Energética de São Paulo

CS - Chapéu do Sol

HP - Horse Power

IBGE - Instituto Brasileiro de Geografia e Estatística

IPT - Instituto de Pesquisas Tecnológicas de São Paulo

$\mathrm{Na}$ - Altônia

NNE - Norte-Nordeste

OPEP - Organização dos Países Exportadores de Petróleo

PETROBRÁS - Petróleo Brasileiro S/A

PR - Paraná

RO - Roncador

RP - Rio Piqueri

SP - SÃO PAULO

SSW - Sul-Sudoeste

TI - Tarabai 


\section{INTRODUÇÃO}

Para configurar a abordagem deste trabalho, é necessário estabelecer os seus contornos.

Inicialmente é dada uma idéia da história da pesquisa de petróleo, que no caso do Estado São Paulo, praticamente se confunde com a pesquisa de petróleo no Brasil, até a formação da Petrobrás em 1953.

Depois da constituição da Petrobrás, a Bacia Geológica do Paraná foi contemplada com dois programas de prospecção de hidrocarbonetos realizados de forma sistemática, com a execução de trabalho na referida Bacia.

O primeiro programa de prospecção foi executado pela Petrobrás até 1974, onde a empresa realizou extenso programa de reflexão sísmica e perfurou 71 poços na Bacia do Paraná. A Petrobrás aplicou todos os recursos técnicos disponíveis na época e devido principalmente às dificuldades de obtenção de seção sísmica de boa resolução, por causa de derrames de basalto, deixou a Bacia do Paraná e passou a investir em outras áreas que ela elegeu como das mais prioritárias, como foi o exemplo da Bacia de Campos.

A partir da formação do Consórcio CESP/IPT em dezembro de 1979, pelo Governo do Estado de São Paulo, foi realizado a segunda pesquisa de exploração sistemática na Bacia Geológica do Paraná. Como será mostrado neste trabalho, foi desenvolvido um esforço concentrado nos anos de 1980, 1981 e 1982, na referida Bacia, pelo Consórcio.

No período entre 1974 e 1980, houve um acentuado desenvolvimento tecnológico na indústria de petróleo que, além de outras áreas, representou um 
avanço dos programas de aquisição e de processamento dos dados de reflexão sísmica.

Este trabalho pretende mostrar, em relação à Bacia Geológica do Paraná, o avanço qualitativo obtido pelo Consórcio CESP/IPT, notadamente no que se refere aos resultados na área de reflexão sísmica da bacia, o que era considerado um tabu até a época, devido aos derrames de basaltos.

Os resultados do programa executado pelo Consórcio CESP/IPT promoveram uma reavaliação da potencialidade e prospectividade da Bacia do Paraná.

Dessa forma, o trabalho considerou principalmente os aspectos qualitativos dos serviços executados. Assim deixaram de ser contempladas apreciações sobre custos, devendo ser esclarecido que todos os investimentos realizados pelo Consórcio foram suportados por recursos financeiros provenientes do tesouro estadual. Esses recursos foram transferidos ao Consórcio CESP/IPT, por meio de "Convênio de Recursos", assinado entre o Consórcio e o Governo do Estado de São Paulo.

O "Convênio de Recursos" estabeleceu todas as regras de transferência e administração dos recursos para o Consórcio, e definiu a respectiva prestação de contas ao Governo do Estado. 


\section{OBJETIVOS}

\subsection{Objetivo Geral}

Mostrar que o Programa de Prospecção executado pelo Consórcio CESP/IPT, na Bacia do Paraná, utilizando-se dos avanços tecnológicos em relação aos anos anteriores, principalmente nos métodos geofísicos, para a pesquisa de petróleo, obteve resultados que proporcionaram uma reavaliação da potencialidade e prospectividade em hidrocarbonetos na referida bacia.

\subsection{Objetivos Específicos}

2.2.1 Evidenciar a aplicabilidade do método de reflexão sísmica na Bacia do Paraná, nos trabalhos executados pelo Consórcio CESP/IPT, demonstrando que os resultados obtidos mudaram o conceito já arraigado de baixa resolução sísmica na referida bacia, repercutindo positivamente na reavaliação da potencialidade e prospectividade em hidrocarbonetos.

2.2.2 Mostrar que os trabalhos de geoquímica, realizados pelo Consórcio CESP/IPT, principalmente nas Formações Ponta Grossa e Irati, apresentaram resultados favoráveis à geração de hidrocarbonetos em áreas pesquisadas pelo Consórcio.

2.2.3 Mostrar que os trabalhos de Engenharia de Perfuração executados pelo Consórcio CESP/IPT numa bacia complexa como a do Paraná, com grandes derrames de basalto, foram otimizados com o desenvolvimento de um 
programa de brocas, eficaz, e uma experiência na dinâmica das perfurações conseguindo-se perfurar 32 poços sem perda de nenhum deles. 


\section{METODOLOGIA}

Considerando que o tema deste trabalho é específico, o método utilizado foi desenvolvido em duas etapas como segue:

\section{a) Pesquisa Bibliográfica}

Realizou-se levantamento bibliográfico, por meio de pesquisas de materiais já elaborados, incluindo obras e publicações sobre a Bacia Geológica do Paraná.

A proposta constou de investigações nas bibliotecas da CESP Companhia Energética de São Paulo, do Instituto de Pesquisas Tecnológicas do Estado de São Paulo - IPT, e consultas à biblioteca da PETRÓLEO BRASILEIRO S/A - PETROBRÁS.

\section{b) Pesquisa Documental}

As pesquisas foram feitas em Relatórios Internos do Consórcio CESP/IPT, em Relatórios Anuais de Atividades da CESP, em Relatórios Anuais de Atividades do IPT, em Relatórios Anuais de Atividades da PETROBRÁS, e em Relatórios do IBGE - Instituto Brasileiro de Geografia e Estatística.

Foram consultados sites ligados ao assunto da tese.

Conseguiram-se relatórios técnicos do acervo de documentos, de empresa que prestou serviços ao Consórcio CESP/IPT, na área de gerenciamento de projetos. 
Foram obtidas colaborações por meio de documentos técnicos pertencentes a especialistas que colaboraram no programa de exploração do Consórcio CESP/IPT.

O material obtido foi sendo catalogado de acordo com o índice de estrutura da tese, para a sua utilização tanto na forma de consulta, como também na forma de consulta e referência. 


\section{SÍNTESE HISTÓRICA DA PESQUISA DE PETRÓLEO}

"Até o começo do século XIX a iluminação nos Estados Unidos foi pouco melhorada em relação à utilizada pelos antigos gregos e romanos. $\mathrm{O}$ desenvolvimento crescente de centros urbanos, com uma necessidade para uma melhor iluminação, e a demanda de crescimento para lubrificantes, provocaram a procura de novas e adicionais fontes de óleo. As baleias estavam tornando-se cada vez mais raras para encontrar, e por volta de meados do século XIX o querosene, ou o óleo de carvão, como era chamado, derivado da destilação do carvão, era de uso comum tanto na Europa como na América. A revolução industrial requeria rapidamente uma nova fonte muito mais barata e mais conveniente que ambos, os lubrificantes e óleo de iluminação, proporcionavam. Deste modo,foi definida a etapa para a conclusão do primeiro poço perfurado especificamente para a pesquisa de petróleo. Este poço, perfurado por E.L. Drake na Pensilvânia ocidental e terminado em agosto de 1859 numa profundidade de 69 1/2 pés $(21 \mathrm{~m})$, criou a indústria de petróleo, logo associada à era industrial moderna. Dentro de curto espaço de tempo, o óleo barato dos reservatórios subterrâneos era refinado em refinarias já existentes de óleo de carvão, e a propagação de descobertas de campos de petróleo antes do século XX cobriu 14 estados desde New York até a Califórnia e do Wyoming até o Texas. Durante o mesmo período os campos de petróleo foram descobertos na Europa e no extremo leste." ${ }^{1}$

As primeiras pesquisas de petróleo no Brasil tiveram início em 1892, na região de Bofete no Estado de São Paulo, por Eugênio Ferreira de Camargo com a perfuração de vários poços, um dos quais atingiu a profundidade de 500 metros 
e produziu água sulfurosa.

No início do século XX, em 1901 e 1902, novas tentativas foram feitas pela Companhia Cruzeiro do Sul sob a supervisão de Arthur B. Reardon.

De acordo com Jesuíno Felicíssimo Jr. "Coube ao Governo do Estado de São Paulo a primazia da abertura da primeira perfuração oficial no Brasil para pesquisa de petróleo, que teve início em 1906, à margem do Ribeirão Jacutinga, a três quilômetros ao sul da cidade de Guarei, à altitude de 630 metros. Foi no Governo de Jorge Tibiriçá e os trabalhos foram de responsabilidade da Comissão Geográfica e Geológica do Estado de São Paulo. O poço foi furado com coroa de diamante e nos testemunhos foi encontrado o primeiro seixo polido e estriado no Brasil, confirmando a presença de rochas glaciais no Estado.

A perfuração atingiu a 138,14 metros e teve uma duração de dois anos, sendo concluída em fins de 1908. O perfil litológico foi de grande valia, para estudos geológicos embora não se tivesse obtido sucesso no que se refere a petróleo "2.

A primeira iniciativa federal na prospecção de petróleo no Brasil aconteceu em 1919 quando o Serviço Geológico e Mineralógico do Brasil, recém criado em 1918 na presidência de Delfim Moreira, iniciou perfurações no Estado do Paraná e, em 1921, perfurou na região de Graminha em São Paulo.

O poço forneceu, pela primeira vez no Brasil aos 310 metros de profundidade, quantidade apreciável de gás natural.

2 - YOSHIDA, R. História da pesquisa de petróleo no Brasil e no Estado de São Paulo. São Paulo, 1978. 
Dando continuidade às pesquisas, foram perfurados vinte poços, sendo que um deles o de Araraguá, deu petróleo a 82,6 metros na Formação Corumbataí. A campanha terminou em 1932.

"Paralelamente, no Estado de São Paulo desenvolveram-se esforços em pesquisas, na gestão de Júlio Prestes de Albuquerque, cujos trabalhos se estenderam de 1928 a 1931.

"Durante o período em que Fernando Costa foi Secretário de Governo do Estado de São Paulo (1928 a 1930) os estudos e locação dos poços foram orientados pelo Geólogo C.W. Washburne, contratado em 1928, na época um dos mais renomados técnicos de petróleo.

Em 1932, a Cia. Petróleo do Brasil, de Monteiro Lobato, iniciou um poço em Araquá, com sonda emprestada pelo Governo do Estado de São Paulo.

Em 1934 o poço atingiu a 1.076 metros em camada de diabásio que consumiu os recursos da Cia. que foi extinta." ${ }^{3}$

Entre 1938 e 1945 aconteceram mais esforços, sem êxito do Governo do Estado de São Paulo.

Em 1946, foi organizada a Sociedade Brasileira de Sondagens, sob a direção técnica de Silvio Fróes de Abreu, que realizou um dos mais sérios serviços de exploração de petróleo na Bacia do Paraná até hoje levado a efeito pela iniciativa privada utilizando sondas do Governo Estadual. Todavia, devido à falta de sucesso, a Companhia encerrou as suas atividades em 1950.

A partir de 1953 com a Lei 2004 a exploração de hidrocarbonetos no Brasil passou a ser monopólio federal executado exclusivamente pela PETROBRÁS.

3 - Ibid, 1978 


\section{COMENTÁRIOS SOBRE AS CRISES DO PETRÓLEO DE 1973 E DE 1979}

Em 1973, a OPEP - Organização dos Países Exportadores de Petróleo, promoveu um acréscimo extraordinário nos preços do barril de petróleo, quase que multiplicando por cinco o seu respectivo preço unitário, o que provocou acentuada mudança no setor mundial de petróleo deixando em situação delicada a economia da maioria dos países importadores de petróleo.

O Brasil que na ocasião importava cerca de $80 \%$ do petróleo que consumia, passou a ter dificuldades na administração de sua crescente dívida externa, em decorrência desse fato.

A Petrobrás que exercia o monopólio na época concentrava o seus investimentos de pesquisa, na Bacia de Campos, no Estado do Rio de Janeiro.

O Governo Federal, diante da situação, verificando a necessidade de ampliação dos investimentos nas áreas de pesquisa de petróleo tomou a decisão de por meio de Contratos de Risco, sem ferir o monopólio, abrir a exploração de pesquisas de hidrocarbonetos, à iniciativa privada nacional e internacional.

Em 1979, novo ajuste da OPEP elevou novamente os preços do barril de petróleo, de forma abrupta, comprometendo ainda mais a economia dos países importadores.

Essas duas crises provocaram, na ocasião, um afluxo mundial na busca de novas jazidas de petróleo.

Como os equipamentos e as equipes de sísmica de reflexão e de perfuração de petróleo, que são as duas principais atividades de um programa 
de exploração de hidrocarbonetos, eram praticamente todos importados, naquela época, havia dificuldade para a contratação desses serviços. 


\section{A CRIAÇÃO DO CONSÓRCIO CESP/IPT}

Em 07 de dezembro de 1979, autorizado pelo governo federal, foi constituído o Consórcio CESP/IPT, para que explorasse petróleo mediante contrato de prestação de serviços com cláusula de risco, a ser negociado com a PETROBRÁS.

O Consórcio aliou a capacidade administrativa e operacional da CESP Companhia Energética de São Paulo à capacidade tecnológica do IPT Instituto de Pesquisas Tecnológicas do Estado de São Paulo. O objetivo do Consórcio CESP/IPT era o de colaborar com o governo federal na localização e exploração de reservas/jazidas de hidrocarbonetos que pudessem ser desenvolvidos até a sua produção comercial, na Bacia Geológica do Paraná.

Quando constituído, era a seguinte a estrutura organizacional do Consórcio CESP/IPT:

> Conselho de Orientação

> Gerência de Exploração

> Gerência de Operação

> Gerência Administrativa

Compunham, na ocasião, o Conselho de Orientação do Consórcio CESP/IPT, o Secretário da Indústria, Comércio, Ciência e Tecnologia, seu Presidente, o Secretário de Obras e do Meio Ambiente, seu Vice-Presidente; dois representantes da CESP, indicados por sua Diretoria, e dois representantes do IPT, indicados por sua Diretoria Executiva. 
As Gerências Geral e de Exploração eram ocupadas por indicação da Diretoria do IPT e as Gerências de Operação e Administrativa eram ocupadas por indicação da Diretoria da CESP.

"Em 11 de dezembro de 1979 o Consórcio CESP/IPT assinou com à Petróleo Brasileiro S/A - PETROBRÁS, dezessete "Contratos de Prestação de Serviços de Exploração de Petróleo, com a cláusula de risco para áreas no Estado de São Paulo, totalizando cerca de $200.000 \mathrm{~km}^{2}$.

Posteriormente em 27/11/1980, foram assinados com a Petrobrás dez contratos de "Prestação de Serviços para Exploração de Petróleo, com cláusula de Risco para áreas fora do Estado de São Paulo, localizadas nos Estados de Mato Grosso do Sul, Goiás, Paraná, Santa Catarina e Rio Grande do Sul" (CONSÓRCIO, 1981).

A Figura 01 mostra a Localização Esquemática dos blocos do Consórcio CESP/IPT, com indicação do Programa de Poços Estratigráficos e Pioneiros.

Na mesma ocasião foi assinado documento devolvendo à PETROBRÁS 7 blocos no Estado de São Paulo, cujos contratos haviam sidos assinados em 11/12/1979.

Esta devolução objetivava a concentração de recursos em áreas mais favoráveis geologicamente.

Desta forma, o Programa Explorativo foi estabelecido para uma área de concessão de cerca de $240.000 \mathrm{~km}^{2}$. 


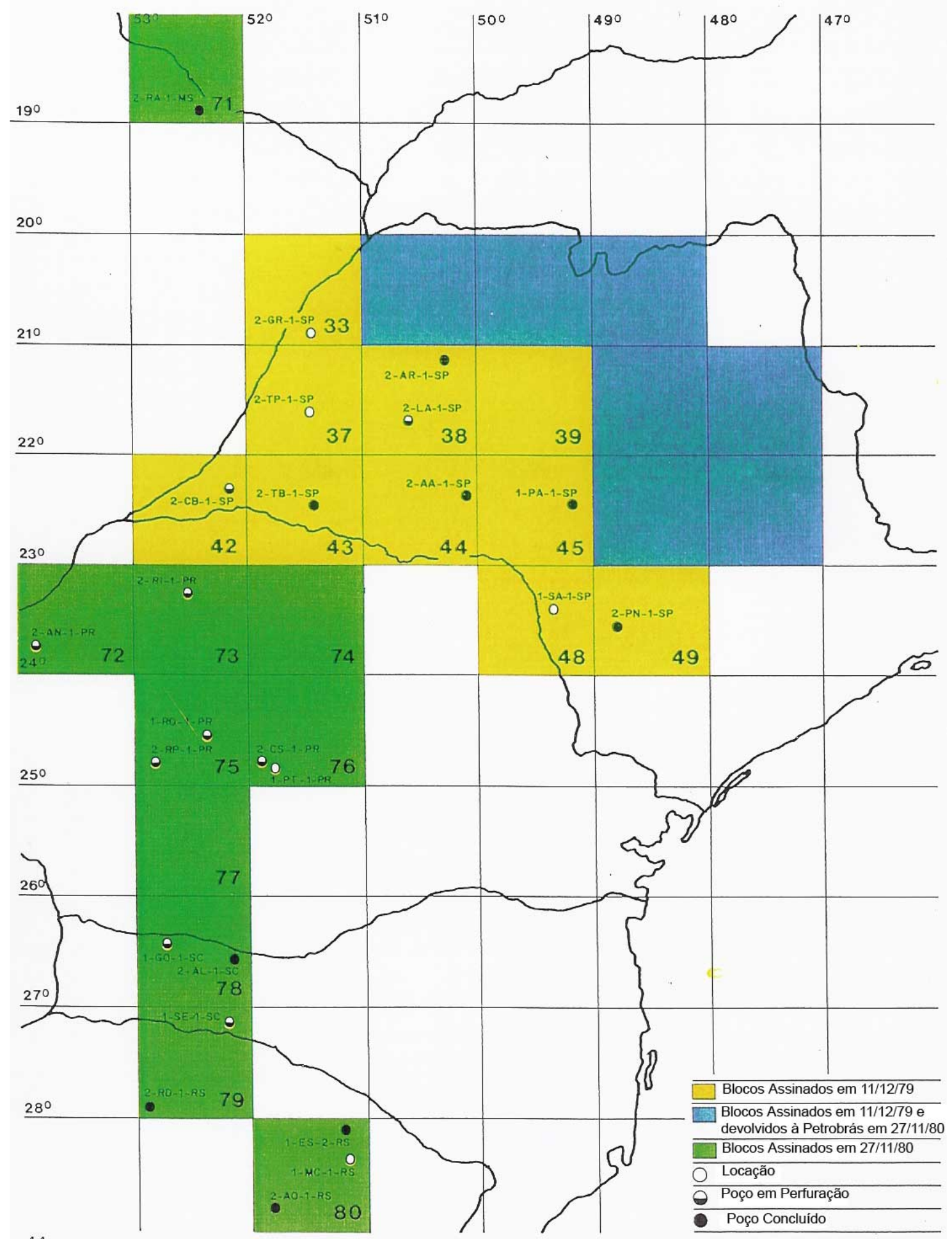

Figura 01 - Localização Esquemática dos blocos do Consórcio CESP/IPT, com indicação do Programa de Poços Estratigráficos e Pioneiros. 


\subsection{A BACIA GEOLÓGICA DO PARANÁ}

"A Bacia do Paraná abrange uma área de cerca de $1.700 .000 \mathrm{~km}^{2}$, estendendo-se pelo Brasil $\left(1.100 .000 \mathrm{~km}^{2}\right)$, Argentina $\left(400.000 \mathrm{~km}^{2}\right)$, e o restante se encontra no Paraguai e Uruguai. Na Argentina e Uruguai, é conhecida por Bacia Chaco-Paraná. Em território brasileiro, a Bacia do Paraná estende-se pelos Estados do Rio Grande do Sul, Santa Catarina, Paraná, São Paulo, Goiás, Mato Grosso e Mato Grosso do Sul. Possui um formato alongado na direção NNE-SSW, que se estende por 1750 km e largura média de 900 km. Com exceção de um estreito cinturão de afloramentos que orla seus limites, as rochas sedimentares da Bacia do Paraná acham-se cobertas por derrames de lavas basálticas que podem atingir 1700 metros de espessura. Na parte central da bacia, a espessura total de rochas sedimentares e vulcânicas atinge 6000 metros." (YOSHIDA e GAMA JR, 1982).

A Figura 02 mostra o Mapa Esquemático da Bacia Sedimentar do Paraná. 


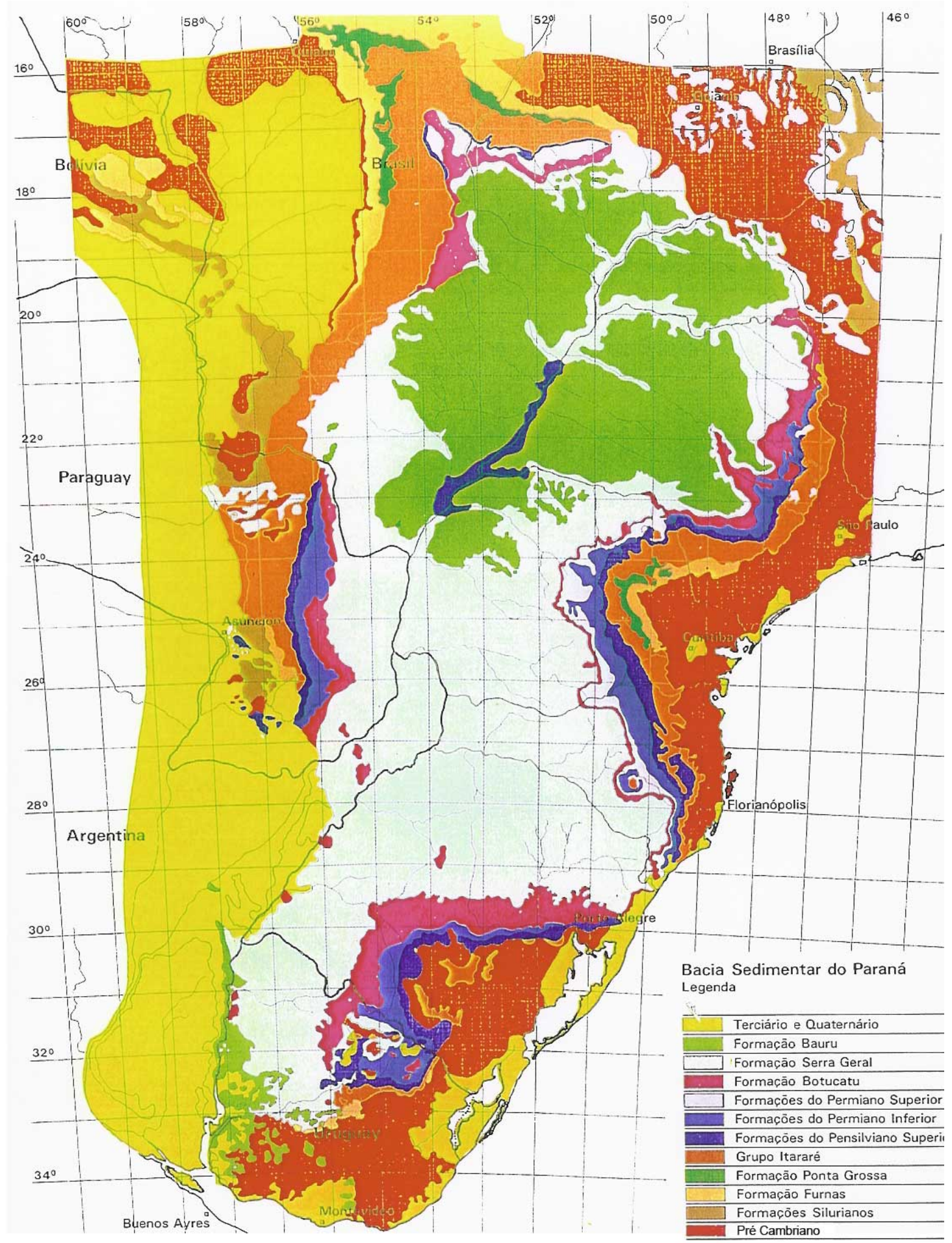

Figura 02 - Mapa Esquemático da Bacia Sedimentar do Paraná.

Fonte: Consórcio CESP/IPT - "Relatório de Atividades" - São Paulo. 1979/1981 


\section{ATUAÇAO DA PETROBRÁS DE 1953 A 1974 NA BACIA DO PARANÁ}

“De 1953 a 1974, foi desenvolvido pela PETROBRÁS um grande esforço sistemático de pesquisa de petróleo na Bacia do Paraná, com a perfuração de 71 poços e aplicação de diferentes métodos de prospecção, freqüentemente em caráter experimental, como a aeromagnetometria, gravimetria e sísmica de reflexão." (YOSHIDA e GAMA JR, 1982).

Estas atividades permitiram desenvolver um valioso acervo nesta bacia. Entretanto, tais dados concentram-se numa faixa territorial limitada, que corresponde a 30\% da extensão total da Bacia do Paraná. Além disso, os 2360 km de linhas sísmicas de reflexão, que é o principal método de pesquisa de hidrocarbonetos na indústria de petróleo não apresentaram resultados promissores, principalmente em áreas de cobertura basáltica, impedindo, portanto, a geração de prospectos estruturais.

"Dentro deste quadro e considerando a situação tecnológica da época, foram delineadas algumas conclusões que, até pouco tempo, eram tidas como verdadeiras: inaplicabilidade da sísmica de reflexão nas áreas de cobertura basáltica, correspondendo a uma extensão geográfica de mais de $70 \%$ da Bacia do Paraná; destruição de eventuais acumulações durante o episódio do vulcanismo, mormente pela elevada densidade de ocorrência de rochas intrusivas basálticas; fraca estruturação da Bacia, durante a deposição das rochas paleozóicas, implicando na pobreza de estruturas acumuladoras; uniformidade dos pacotes sedimentares, em toda a bacia, com uma estratigrafia desfavorável à ocorrência de acumulações significativas; e, finalmente, relação temporal inadequada entre a geração de hidrocarbonetos, 
considerada de idade paleozóica, com a principal etapa de estruturação da Bacia, de idade mesozóica." (YOSHIDA e GAMA JR 1982).

Por outro lado, foram obtidas também algumas conclusões que contribuíram positivamente para possibilitar a presença de acumulações de hidrocarbonetos: abundância de reservatórios de boa qualidade em toda a seção sedimentar; relação espacial adequada entre rochas geradoras e rochas reservatório; existência de estruturas na faixa de afloramentos com possibilidades de estruturação para o interior da bacia e, a existência de bons geradores e comprovação de geração com riqueza de indícios e até alguma produção de óleo/gás no programa de perfuração executado. 


\section{TRABALHOS EXECUTADOS PELO CONSÓRCIO CESP/IPT NA BACIA DO PARANÁ}

\subsection{Aspectos Gerais}

O Quadro 1 a seguir sintetiza os dados geológicos adquiridos pelo Consórcio CESP/IPT, nas atividades desenvolvidas no decorrer dos anos de 1980, 1981 e 1982, nos 240.000 km2 de sua área de concessão nos contratos de risco.

Há de se acrescentar, ainda, uma quantidade considerável de análises petrográficas, geoquímicas, petrofísicas e paleontológicas.

Quadro 1

\begin{tabular}{|l|c|}
\hline \multicolumn{1}{|c|}{ ATIVIDADE } & TOTAL \\
\hline Mapeamento Geológico Sistemático, na escala 1:100.000 & $240.000 \mathrm{~km}^{2}$ \\
\hline Análise Morfoestrutural de Imagem de Satélite, na escala 1:250.000 & $240.000 \mathrm{~km}^{2}$ \\
\hline Análise Morfoestrutural em Fotos Aéreas, na escala 1:60.000 & 86 áreas $-57.436 \mathrm{~km}^{2}$ \\
\hline Mapeamento de Detalhe, na escala 1:25.000 & 42 áreas - 22.435 km² \\
\hline Levantamento de Seções Estratigráficas & $815 \mathrm{~km}$ \\
\hline Levantamento Aeromagnetométrico & $243.734 \mathrm{~km}^{2}$ \\
\hline Sondagens Elétricas Verticais & 243 \\
\hline Sondagens Magnetotelúricas & 750 \\
\hline Reflexão Sísmica & 10 poços - $2.057 \mathrm{~m}$ \\
\hline Sondagem Estrutural Rasa & 13 \\
\hline Poços Estratigráficos Concluídos & $196.263 \mathrm{~m}$ \\
\hline Poços Pioneiros Concluídos & 96.115 \\
\hline Metros Perfurados & \\
\hline
\end{tabular}

Fonte: Riuiti Yoshida e Ercílio Gama Jr. (1982). 
A partir do quadro resumo dos trabalhos executados pelo Consórcio CESP/IPT na sua área de concessão na Bacia do Paraná, são detalhados serviços realizados nas áreas de geofísica (sísmica de reflexão), geoquímica e engenharia de perfuração, que inclui os serviços associados de programas de brocas e testes de formação.

\subsection{Sísmica}

\subsection{1 Áreas de Aplicação}

"Existem algumas razões para que a geofísica de exploração tenha poucas aplicações na pesquisa de engenharia de minas, quando comparada à indústria de petróleo.Basicamente, as propriedades físicas das estruturas minerais não oferecem grande contraste com as propriedades correspondentes das rochas que as englobam.

Além do mais, as companhias de minas são menos importantes do que as de petróleo.

O grande investimento em sísmica de reflexão nas pesquisas da indústria de petróleo justifica-se depois da descoberta de uma jazida promissora.

No Brasil, com exceção da indústria de petróleo, as aplicações da geofísica são restritas a pequenas profundidades (ao redor de $30 \mathrm{~m}$ ), na pesquisa de depósitos de areias para uso na construção civil, na determinação de camadas superficiais de cascalhos e de pedras e na determinação de áreas contaminadas por metal pesado." (LEAL FILHO et al, 1996). 
As pesquisas de águas subterrâneas que alcançam maiores profundidades, em torno de 300 m, geralmente são feitas por agências estaduais em regiões secas.

$\mathrm{Na}$ indústria privada, esse tipo de pesquisa, por questões de tempo e de custos, sofre uma grande concorrência da radiestesia.

\subsubsection{Métodos Sísmicos}

"A Sísmica é um dos mais importantes métodos de Prospecção Geofísica para petróleo. Baseia-se no estudo de propagação de ondas elásticas criadas artificialmente (em superfície) por meio de explosivos ou de sistema "vibroseis". As ondas elásticas se propagam pelas diferentes rochas da crosta com diferentes velocidades. Assim, rochas ígneas e metamórficas apresentam, em geral, velocidade de propagação maiores do que as rochas sedimentares. É graças a esse contraste de velocidades que se torna possível o uso dos métodos sísmicos. Os métodos sísmicos são subdivididos em Sísmica de Reflexão e Sísmica de Refração." (Instituto, 1979).

\subsubsection{Sísmica de Reflexão}

É um método muito utilizado na prospecção de petróleo e gás. Consiste na emissão de ondas (ou pulsos) que se propagam em todas as direções, refletindo nas interfaces entre os vários estratos geológicos que apresentam diferentes impedâncias acústicas, retornando à superfície. Este fenômeno se dá de acordo com a Lei da Reflexão. 
Permite investigações a grandes profundidades e fornece informações completas (quantitativas) sobre estruturas geológicas ocorrentes em subsuperfície. É utilizada como detalhamento de estruturas, em geral, previamente detectadas pela gravimetria, magnetometria e método MagnetoTelúrico, que são três importantes métodos de prospecção geofísica.

Além da gravimetria e magnetometria, na pesquisa de prospecção executada pelo Consórcio CESP/IPT também foram usados dados obtidos pelo método Magneto-Telúrico, que foi utilizado pela primeira vez em pesquisa de hidrocarbonetos no país.

\subsubsection{Sísmica de Refração}

A Sísmica de Refração é utilizada em menor escala do que a Sísmica de Reflexão para prospecção de petróleo e gás, pois tem a profundidade de investigação limitada pela existência de camadas refratoras. Entretanto, em alguns casos é recomendável para identificação e caracterização em termos quantitativos de camadas superficiais ("overburden").

\subsubsection{Sísmica de Reflexão na Bacia do Paraná}

A aquisição e o processamento de dados sísmicos obtidos pela PETROBRÁS até o início da década de 1970, na Bacia Geológica do Paraná, devido aos grandes derrames de basalto na bacia, produziram resoluções sísmicas de resultados insatisfatórios, que desestimularam as pesquisas sistemáticas de hidrocarbonetos, levando a empresa a concentrar seus 
esforços em outras áreas de maior interesse. Devido a esse fato, a referida bacia permaneceu, por muito tempo, praticamente sem investigação.

A retomada dos levantamentos sísmicos, efetuada pelo Consórcio CESP/IPT a partir de 1980, utilizando-se de equipamentos e softwares mais modernos, conseguindo-se seções sísmicas de melhor resolução, proporcionaram uma reavaliação de potencialidade e prospectividade em hidrocarbonetos na Bacia Geológica do Paraná.

Nas pesquisas anteriores, as camadas de basalto da bacia funcionaram como obstáculo para a energia acústica emergente, reduzindo sensivelmente a parcela refletida à superfície que é registrada pelos receptores, durante as operações da reflexão sísmica.

Os técnicos do Consórcio CESP/IPT, observando que nas seções sísmicas obtidas anteriormente ocorriam evidências de refletores em diversos níveis, e levando em conta o progresso obtido nos softwares mais avançados, resolveram reprocessar os dados adquiridos anteriormente, tendo conseguido substancial melhora na qualidade dos mesmos.

Este fato encorajou a intensificação de um programa de aquisição de dados sísmicos, utilizando-se de equipamentos modernos de obtenção de dados, o que acabou sendo bem sucedido, propiciando um estímulo ao programa de exploração do Consórcio.

Deste modo se tornou viável a resolução sísmica na Bacia Geológica do Paraná, demonstrando a aplicabilidade do método de reflexão sísmica na referida bacia. 
Assim sendo, o Consórcio CESP/IPT contratou e colocou em operação 6 (seis) equipes sísmicas, sendo 5 (cinco) com o sistema "vibroseis" como fonte de energia e uma que usou dinamite.

A Figura 03 mostra o Mapa Esquemático de Localização das Equipes Sísmicas

As nomenclaturas das equipes de sísmica (ES) foram as seguintes:

- com sistemas vibroseis como fonte de energia

- $\quad E S-72$

- $\quad E S-76$

- $\quad$ ES -77

- $\quad E S-113$

- $\quad E S-114$

- com dinamite como fonte de energia

- $\quad E S-120$

A Figura 04 apresenta a Vista de uma Equipe de Sísmica de Reflexão no campo.

\subsubsection{Aquisição de Dados Sísmicos}

"A seguir são apresentados os parâmetros básicos (com pouca variação de uma equipe para outra), adotados pelas cinco equipes de sísmica, na aquisição de dados, que utilizam o sistema "vibroseis" como fonte de energia." (SILVA e VIANNA, 1982).

Instrumento: DFS - V 
$N^{\circ}$ de canais: 96

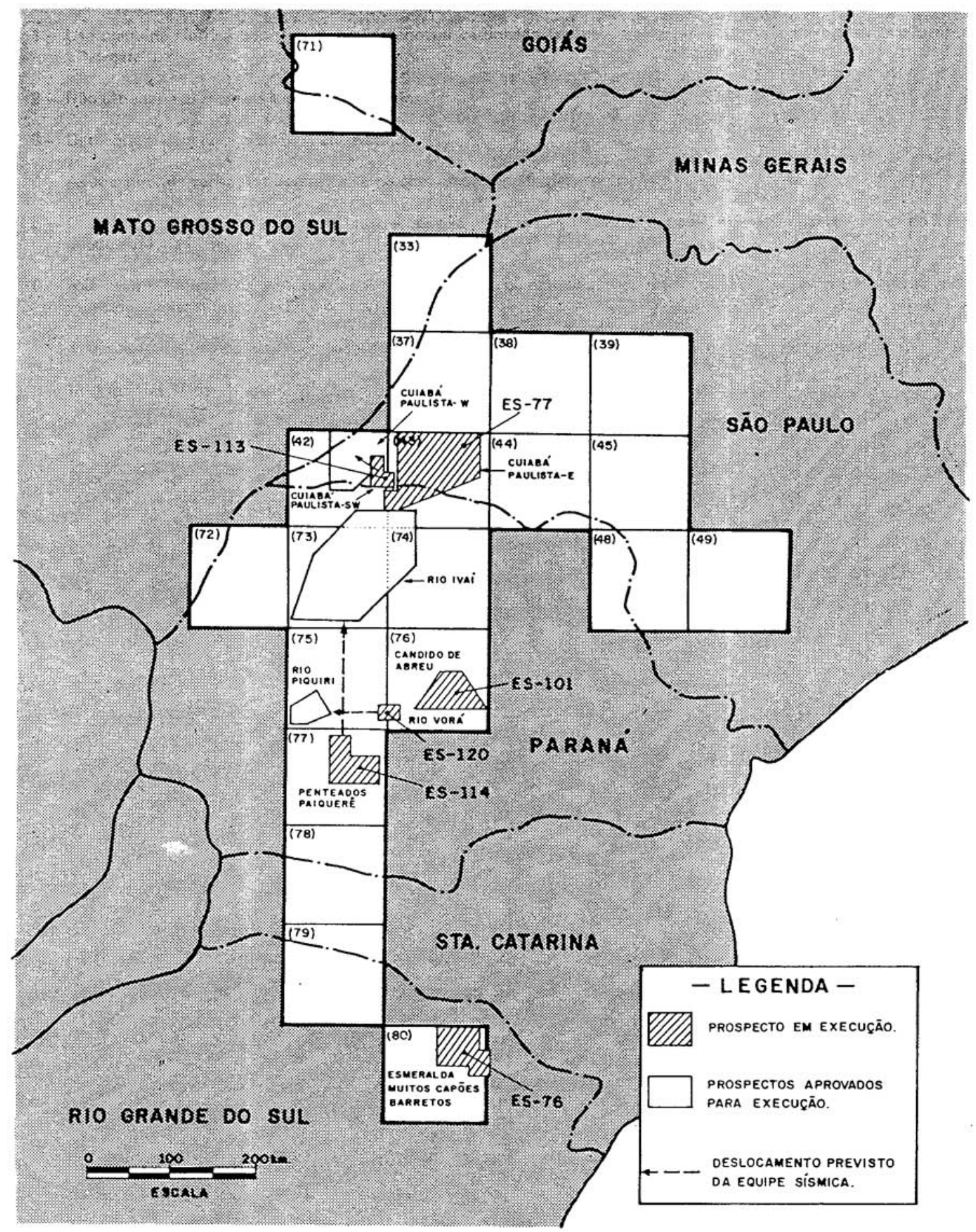

Figura 03 - Mapa Esquemático de Localização das Equipes Sísmicas

Fonte: Consórcio CESP/IPT - Geologia da Bacia do Paraná - Reavaliação da Potencialidade e Prospectividade em Hidrocarbonetos.São Paulo. 1982. 


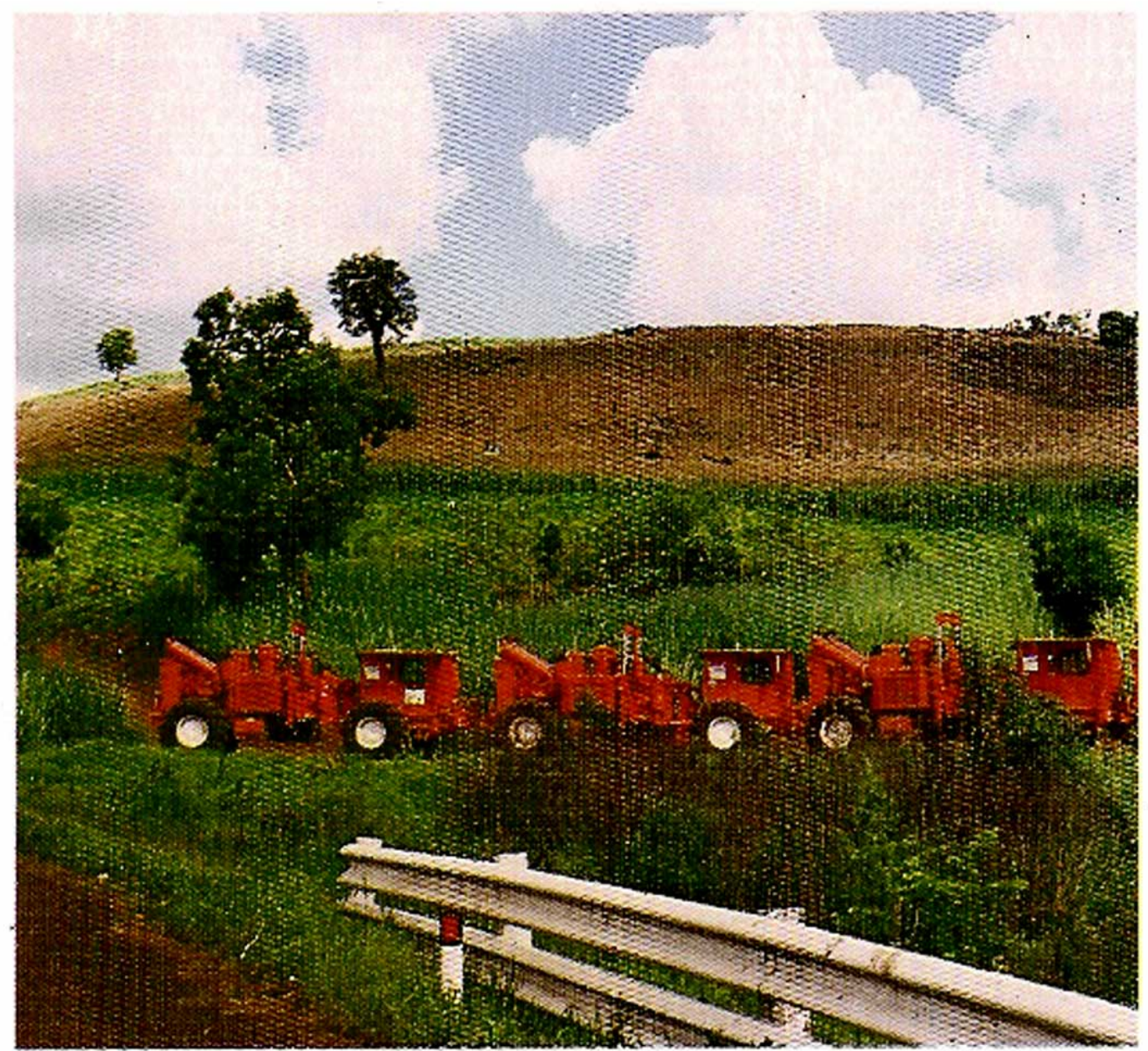

Figura 04 - Vista de uma Equipe de Sísmica de Reflexão no campo.

Fonte: Consórcio CESP/IPT - Geologia da Bacia do Paraná - Reavaliação da Potencialidade e Prospectividade em Hidrocarbonetos. São Paulo. 1982. 
Formato: SEGB 1600 BPI 9 Tracks

Ganho: IFP

Amostragem: 4 milissegundos

Filtros: $18 / 128 \mathrm{~Hz}$

Slopes: 18 e 72 db/oit

Filtro Notch: $\ln (60 \mathrm{~Hz})$

No Vibradores: 4

Int. Vibradores: $32-25-32 m$

Sempre se trabalhou, por exigência dos geofísicos do Consórcio com quatro vibradores. Portanto entre $\circ 1^{\circ}$ e $2^{\circ}$ vibrador o intervalo era de 32 metros, entre o $2^{\circ}$ e $3^{\circ}$ de $25 \mathrm{~m}$ e entre o $3^{\circ}$ e $4^{\circ}$ de $32 \mathrm{~m}$.

Avanços: entre PVs - 9m

Freq. Sweep: 14/85 Hz

№ Sweep: 18

Tempo Sweep: 16 seg.

Comp. Reg.: 4 seg.

Int. PVS: 150m

Int. Est. Geof.: 50m

Cobertura: CDP - $1600 \%$

Lanço: 2225-475-0-475-3425- bipartido assimétrico

Arranjo Geofs.: 36 em linha equiespaçados de $4 \mathrm{~m}$

Tipo Geof.: $\mathrm{L}-10 \mathrm{~A}-10 \mathrm{~Hz}$ 
A equipe ES-120, que utilizou a dinamite como fonte de energia, usou os seguintes parâmetros:

Instrumento: DFS - V da TI

$N^{\circ}$ de Canais: 96

Formato: SEG B

Ganho: IFP

Amostragem: 2 milissegundos

Tempo de Registro: 3s (Esta equipe trabalhou em áreas de menor profundidade).

Filtros: $12 / 128 \mathrm{~Hz}$

Pendente: $18 \mathrm{db} /$ oit $-72 \mathrm{db} /$ oit

$N^{\circ}$ de Furos: 16

Profundidade: $2 \mathrm{~m}$ ou topo rochoso

Carga por furo: $1 \mathrm{~kg}$ gelatina sismográfica

Cobertura CDP: $2400 \%$

Lanço: bipartido simétrico, 2650-300-0-300-2650

Int. entre estações: $50 \mathrm{~m}$

Int. entre P.T.s.: $100 \mathrm{~m}$

Tipo de Geofones: GSC 20 D 10Hz

Arranjo de Geof.: Linear centrado na estaca, 36 por estação

Int. entre Geof.: 4,3 metros 
Processamento no campo por Vigilant para controle de qualidade. Instalou-se no campo centro de processamento exclusivamente para controle de qualidade dos registros, o que nunca havia sido feito anteriormente."(SILVA e VIANNA, 1982).

\subsubsection{Processamento de Dados Sísmicos}

"Para a seqüência de processamento, os programas utilizados foram os seguintes:

DEMUX - Demultiplexação dos dados

VIBCOR - Correlação dos registros de campo filtrados

SCALE - Recuperação do ganho usando a curva $G(d b)=4,5(T)+0,75$ $(20 \log \mathrm{T})+40$, onde 4,5 representa a compensação da perda de energia pela atenuação inelástica; 0,75 - é a compensação da perda de energia pela divergência esférica; 40 - é o fator de ajuste do nível final.

FILTER - Normal ou variável com o tempo: 0/3000 Mseg; 5/15-60/80Hz

DECON - Fase zero com segundo cruzamento por zero. Operador: "GAP" 34 milisegundos e "LENGTH" 320 milissegundos.

Janelas: Traço próximo 350/3000Mseg. Traço afastado 900/3000Mseg.

SORT (SLORT) - Ordenamento dos pontos comuns de profundidade. (para linhas com grandes curvaturas).

STATIC - Correções estáticas.

VELSTK - Análises de velocidade por estaqueamento.

CDS - Estaqueamento de distâncias comuns. 
NMO - Correções de "move-out".

MUTE - Supressão das primeiras quebras. $2225 \mathrm{~m} / 0,5$ seg. $475 \mathrm{~m} / 0,25$ seg. $3425 / 0,8$ seg.

SCANRS - Correções estáticas consistentes superficiais com "shift" máximo de 10Mseg. E janela de 0,600/0,900 segs.

STACK - Cobertura múltipla de $1600 \%$.

FILTER - Normal ou variável com o tempo: 0/3,0seg $5 / 18-60 / 80 \mathrm{~Hz}$

BALANS - Balanceamento dos traços.

FREEDOM - Aplicação de filtros de velocidade e coerência.

SSD - Seção sísmica." (SILVA e VIANNA, 1982)

De 1980 a 1982, o Consórcio CESP/IPT executou 5.115km de linhas de reflexão sísmica.

"Depois de serem processados cerca de $3.000 \mathrm{~km}$ de linhas de reflexão sísmica, a qualidade dos dados obtidos está assim distribuída:

$$
\begin{aligned}
& \text { Bom }-55 \% \\
& \text { Regular }-20 \% \\
& \text { Deficiente }-25 \%
\end{aligned}
$$

Esses dados correspondem aos bons níveis de qualidade obtidos em outras bacias sedimentares, sem cobertura basáltica e intrusões vulcânicas." (SILVA e VIANNA, 1982). 
Os $75 \%$ de classificação bom e regular ofereceram condições reais de contribuírem na pesquisa de hidrocarbonetos, indicando áreas favoráveis à acumulação.

"Pela primeira vez na Bacia do Paraná foram realizados processamentos por atributo (freqüência, comprimento de onda, amplitude), dando origem a seções sísmicas em que os horizontes refletores e as características das ondas sísmicas eram apresentados em seções sísmicas coloridas. Dada a inexistência, na época, de centros de processamento no Brasil, os dados foram processados na Austrália, mostrando excelente qualidade." (GALHANO et al, 2006a).

A Figura 05 mostra o Prospecto de seção de Linha Sísmica passando pelo Poço 2-CB-1- Cuiabá Paulista - SP e a Figura 06 mostra o Prospecto de seção de Linha Sísmica na área de Rio Vorá - PR. 

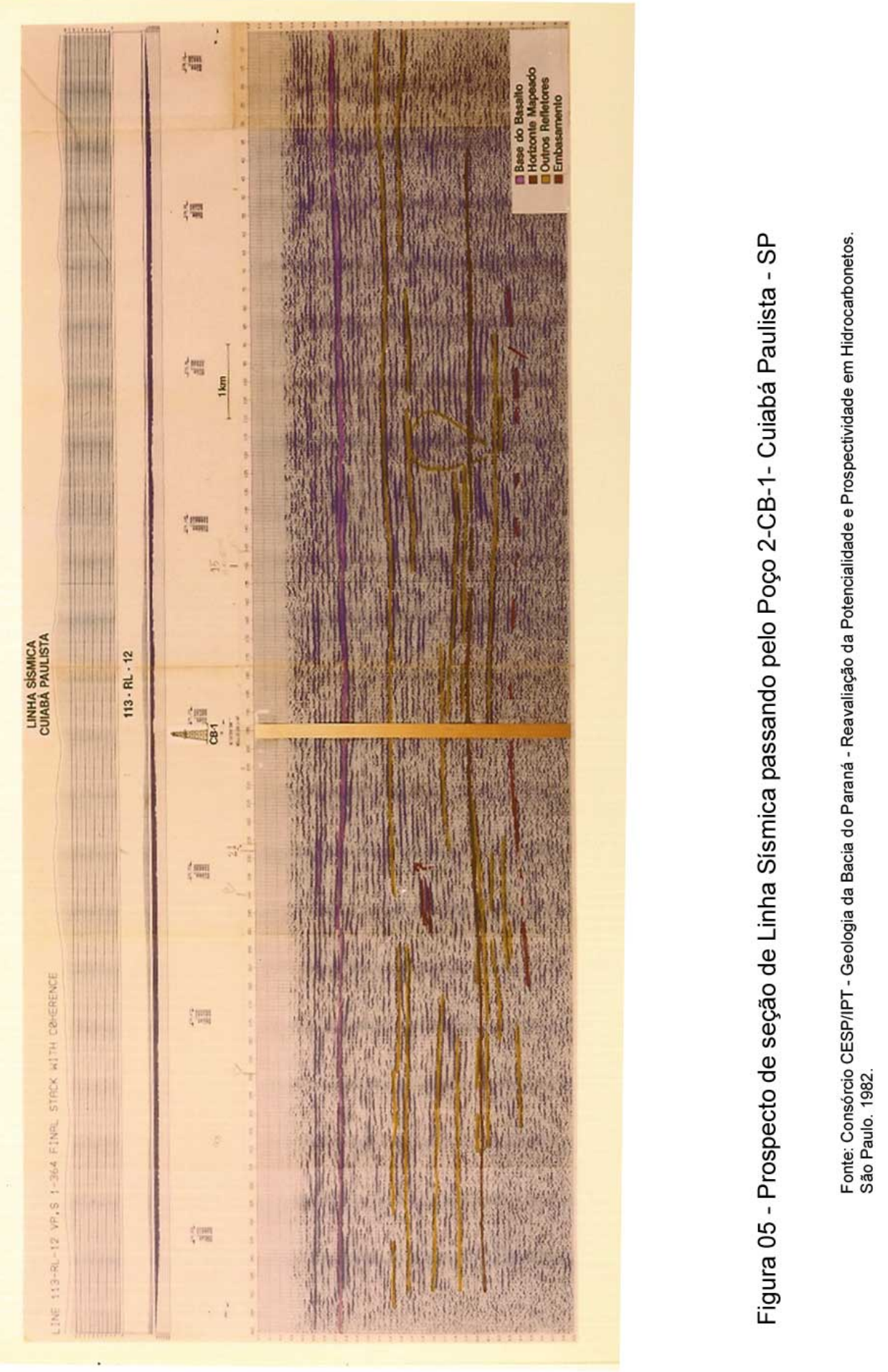


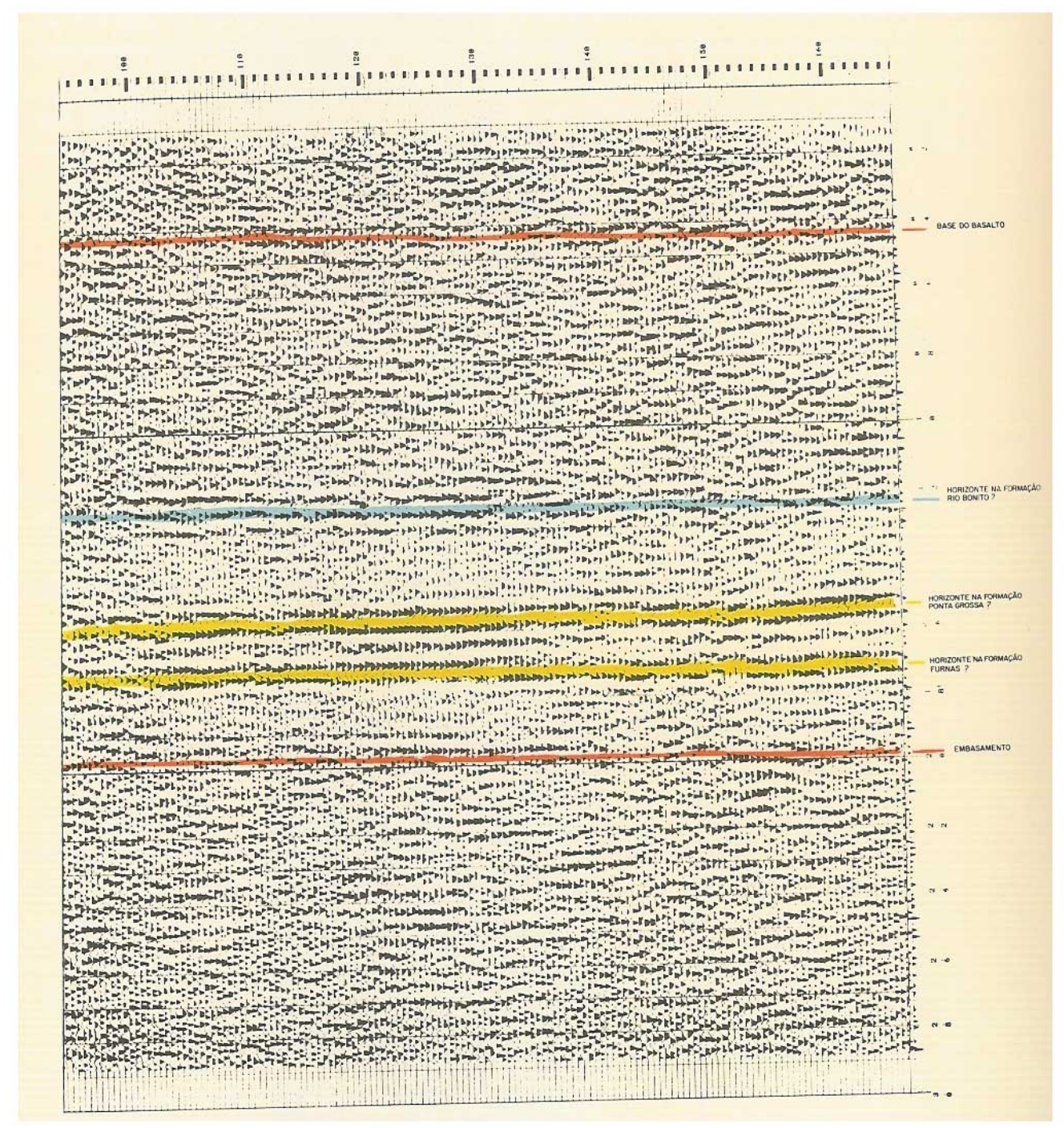

Figura 06 - Prospecto de seção de Linha Sísmica na área de Rio Vorá - PR

Fonte: Consórcio CESP/IPT - Geologia da Bacia do Paraná - Reavaliação da Potencialidade e Prospectividade em Hidrocarbonetos. São Paulo. 1982. 


\subsection{Geoquímica da Bacia do Paraná}

\subsubsection{Geoquímica das Formações - Ponta Grossa e Irati na Bacia do Paraná}

O Consórcio CESP/IPT procurou desde sua formação em dezembro de 1979 instalar um laboratório de ensaios e análises geoquímicas, ao mesmo tempo em que preparava a formação de equipe técnica para o desenvolvimento das atividades na área.

A partir de julho de 1980 foram iniciadas as obras do Laboratório de Ensaios e Análises e sua capacidade de instalação foi completada em janeiro de 1981, o que possibilitou o início dos trabalhos geoquímicos pelo Consórcio CESP/IPT. A PETROBRÁS já havia iniciado os primeiros trabalhos geoquímicos na Bacia do Paraná, por meio do seu Centro de Pesquisas e Desenvolvimento - CENPES.

Após a implantação do laboratório de ensaios e análises do Consórcio CESP/IPT, no começo de 1981, tiveram início as primeiras análises geoquímicas em amostras de poços perfurados pelo próprio Consórcio, e em algumas amostras cedidas pela PETROBRÁS de poços perfurados por ela localizados na área de concessão do Consórcio.

“Em função dos resultados dessas análises foi possível a execução pelo Consórcio, da avaliação de formações da Bacia do Paraná que apresentaram os melhores parâmetros por serem classificadas como potencialmente geradoras, ou seja, formações Ponta Grossa e Irati." (GOULART e JARDIM, 1982). 
Conforme mencionado na referida avaliação foram utilizados os dados obtidos pelo Consórcio a partir de amostras de seus poços e de poços da PETROBRÁS situados na área de concessão do Consórcio.

O Quadro 2, a seguir, apresenta os poços considerados no trabalho de avaliação geoquímica executado pelo Consórcio CESP/IPT.

\begin{tabular}{|c|c|c|c|}
\hline $\begin{array}{c}\text { Sigla do Poço Consórcio } \\
\text { CESP/IPT }\end{array}$ & $\begin{array}{l}\text { Formação } \\
\text { Analisada }\end{array}$ & $\begin{array}{l}\text { Sigla do Poço } \\
\text { PETROBRÁS }\end{array}$ & $\begin{array}{l}\text { Formação } \\
\text { Analisada }\end{array}$ \\
\hline $2-C B-1-S P$ & $\mathrm{PG} / \mathrm{IR}$ & $2-\mathrm{PP}-1-\mathrm{SP}$ & PG/IR \\
\hline 2 - TB - 1 - SP & $P G / I R$ & 2 - LI - 1 - SP & IR \\
\hline 2 - PN - 1 - SP & PG/IR & 1 - AT - 1 - SP & IR \\
\hline $2-A R-1-S P$ & $P G / I R$ & $2-G U-3-S P$ & IR \\
\hline 2 - LA - 1 - SP & PG/IR & 1 - JT - 1 - PR & PG/IR \\
\hline $2-A A-1-S P$ & IR & $2-A P-1-P R$ & PG \\
\hline 2 - PA - 1 - SP & IR & $2-C M-1-P R$ & $P G$ \\
\hline $2-R I-1-P R$ & $P G / I R$ & 1 - CA - 2 - PR & PG \\
\hline 2 - NA - 1 - PR & $P G / I R$ & 1 - CA - 1 - PR & PG \\
\hline 2 - RP - 1 - PR & $P G / I R$ & 2 - LS - 1 - PR & PG/IR \\
\hline 1 - RO - 1 - PR & $P G / I R$ & 1 - SJ - 1 - PR & $P G / I R$ \\
\hline 2 - CS - 1 - PR & $P G / I R$ & $2-O-1-P R$ & PG/IR \\
\hline $2-A L-1-S C$ & IR & $2-M O-1-P R$ & PG \\
\hline 1 - SE - 1 - SC & IR & $2-J-1-P R$ & PG/IR \\
\hline 1 - RD - 1 - RS & IR & $2-\mathrm{CN}-1-\mathrm{SC}$ & $P G$ \\
\hline 1 - ES - 2 - RS & IR & 1 - TP - 2 - SC & IR \\
\hline $2-\mathrm{AO}-1-\mathrm{RS}$ & IR & $1-B N-1-S C$ & IR \\
\hline 2 - RA - 1 - MS & $P G / I R$ & $2-A L-1-R S$ & IR \\
\hline \multirow{5}{*}{\multicolumn{2}{|c|}{$\begin{array}{l}\text { PG - Formação Ponta Grossa } \\
\text { IR - Formação Irati }\end{array}$}} & $2-\mathrm{TL}-1-\mathrm{MT}$ & PG \\
\hline & & 2 - RP - 1 - MT & PG \\
\hline & & 1 - AG - 1 - MT & PG \\
\hline & & 2 - DO - 1 - MT & PG \\
\hline & & $2-J A-1-G O$ & PG \\
\hline
\end{tabular}

Fonte: Goulart E.P. e Jardim N.S. (1982).

Considerando a metodologia utilizada pelas técnicas do Consórcio, diversos parâmetros geoquímicos possibilitaram definir o potencial gerador das rochas oferecendo subsídios para a resolução dos problemas relacionados às interpretações geológicas.

"Para que uma rocha seja classificada como geradora é necessário que as seguintes condições sejam satisfeitas:

> Contenha matéria orgânica em quantidade adequada; 
A matéria orgânica seja capaz de gerar hidrocarbonetos (qualidade adequada);

A rocha tenha sido submetida a temperaturas necessárias para geração (maturação adequada);

A rocha possua espessura e extensão adequadas para geração de quantidades substanciais de petróleo." (GOULART e JARDIM, 1982).

A avaliação geoquímica efetuada pelo Consórcio CESP/IPT, baseada principalmente em informações obtidas a partir de amostras de poços situados nas áreas de concessão do Consórcio, mostrou que as formações Ponta Grossa e Irati são as que apresentaram as melhores características para a geração de hidrocarbonetos na Bacia do Paraná.

"A formação Ponta Grossa apresenta teor médio de carbono orgânico de $0,5 \%$. A caracterização dessa matéria orgânica possibilitou a identificação de uma área de predominância de material de origem marinha e/ou mista a oeste, enquanto que a leste predomina material de origem continental." (GOULART e JARDIM 1982).

Os estudos mostraram que a entrada dos sedimentos na zona de maturidade deu-se no início da época de atividade magmática, motivada pelo aumento de soterramento, associado a variações no gradiente geotérmico.

Embora não houvesse condições de delimitação precisa das áreas com diferentes graus de maturidade, foi constatado que na região situada entre os poços 2 - CB - 1 - SP e 2 - CS - 1 - PR a Formação Ponta Grossa situa-se dentro da zona de geração de gás. 
Os estudos mostram que quatro zonas com diferentes potencialidades iniciais puderam ser delimitadas: muito boa, boa, regular e pobre. As duas primeiras estão relacionadas em parte à área onde o Consórcio detectava zona de geração de gás.

"A Formação Irati apresentou teor médio por poço de $1 \%$ de carbono orgânico (máximo de 3\% e mínimo de 0,3\%). Nas partes central e oriental de ocorrência da formação predomina matéria orgânica de origem marinha e/ou mista, enquanto que para oeste e noroeste observa-se predominância de material de origem continental." (GOULART e JARDIM, 1982).

Os resultados obtidos pelas análises geoquímicas realizadas pelo Consórcio CESP/IPT com amostras retiradas principalmente das Formações Ponta Grossa e Irati, mostraram que a matéria orgânica se encontrava em estado de maturidade suficiente, em condições de gerar hidrocarbonetos. 


\subsection{Engenharia de Perfuração na Bacia do Paraná}

Durante a fase de pesquisa de um programa de prospecção de petróleo, dois tipos de poços são perfurados:

- Poços Estratigráficos

Os Poços Estratigráficos são poços de estudo da bacia pesquisada, e são perfurados com várias interrupções durante a perfuração, para a realização de operações de amostragem e testemunhagem das camadas de perfuração com a finalidade de confirmar ou determinar a estratigrafia da região perfurada. Também são realizadas outras operações como perfilagem elétrica para o estudo das formações.

Como a hora trabalhada de uma sonda é cara, e quando se para a perfuração para as operações de amostragem, testemunhagem, perfilagem elétrica e outras como troca de brocas, revestimento e cimentação do poço, nas mesmas condições, um poço estratigráfico custa mais do que um poço pioneiro.

- Poços Pioneiros

O Poço Pioneiro tem finalidade distinta do poço estratigráfico. Por meio de levantamentos sísmicos e outros métodos, identifica-se uma estrutura em profundidade.

O poço pioneiro é perfurado para testar esta estrutura, e verificar se ela contém óleo ou gás.

Portanto, o poço pioneiro é furado sem interrupção, a não ser para a troca de brocas, o revestimento e a cimentação. Desse modo, na perfuração de 
um poço pioneiro, se gasta bem menos hora de sonda do que num poço estratigráfico. Assim, o custo de um poço pioneiro é bem menor.

\subsubsection{Perfuração de Poços}

A perfuração de poços para petróleo ou gás, tanto para pesquisas de jazidas como para desenvolvimento de campos, representa a maior parcela de investimento num Programa de Exploração.

Uma vez tomada a decisão para perfurar num determinado local, com a finalidade de pesquisa para encontrar hidrocarbonetos, várias providências ocorrem.

\subsubsection{Preparação do Local}

As operações básicas de preparação do local no continente incluem a limpeza do local, a terraplanagem da área, a construção do tanque de lama, as vias de acesso e a implementação da infraestrutura básica como: fornecimento de água, depósitos, oficinas, escritórios, fornecimento de energia elétrica, acomodações para pessoal técnico, pois a sonda opera 24 horas por dia. As necessidades específicas para cada poço, variam de local para local e dependem do tipo de equipamento.

\subsubsection{Transporte e Instalação da Sonda}

O transporte de uma sonda de perfuração representa uma atividade delicada e especializada. Se a sonda vem desmontada, os custos são elevados. No transporte de um equipamento de uma locação para outra, a curta distância, a sonda pode ser transportada em poucas partes, por meio de 
carretas pesadas. A instalação do equipamento em geral é feita pela equipe que vai trabalhar na perfuração do poço.

\subsubsection{Equipe de Trabalho de Perfuração}

Na perfuração de um poço em busca de hidrocarbonetos, o trabalho de equipe no campo é fundamental.

Ele inclui um conjunto de pessoas de várias áreas como a engenharia de perfuração, a geologia, a turma de perfuração, o pessoal de serviços próprios e as companhias de serviços associados à perfuração.

\subsubsection{Como se Perfura}

"Nas bacias sedimentares as rochas se dispõem em camadas com diferentes composições e propriedades físicas. O objetivo da perfuração é atravessar essas camadas de sedimentos, até que se atinja as zonas de interesse."4 . Os poços, em geral, são perfurados por etapas. Inicia-se o furo com um determinado diâmetro, e perfura-se até uma certa profundidade. Em seguida, reveste-se o trecho perfurado com tubos de aço com diâmetro um pouco menor que o do trecho perfurado. O espaço entre a parede do poço e a parte externa do tubo de revestimento, chamado de espaço anular, é preenchido com uma camada de cimento líquido, numa operação denominada cimentação. Após o cimento endurecer, dá-se continuação à perfuração com um diâmetro menor até se atingir nova profundidade. Reveste-se novamente o poço até a superfície e cimenta-se o espaço anular, assim por diante, até que sejam atingidas as formações de interesse.

$\overline{4-K A C H A N, ~ E . ~ C . ~ C u r s o ~ d e ~ P e r f u r a c ̧ a ̃ o . ~ S a ̃ o ~ P a u l o, ~} 2005$. 
O projeto prévio de perfuração de um poço de petróleo prevê os diâmetros das diversas fases, seus revestimentos e profundidades de assentamentos, bem como as técnicas de perfuração. Os materiais a serem utilizados são dimensionados em função da área a ser perfurada, das características das formações a serem atravessadas e das profundidades finais dos poços. A principal finalidade do primeiro revestimento, chamado de Revestimento de Superfície, é isolar as formações ainda não consolidadas, no começo dos furos. Também devem ser isolados os lençóis freáticos, quando existirem. Em seguida, são feitos os revestimentos intermediários, que têm como finalidade isolar aqüíferos embutidos, evitando sua contaminação. Visam, também, isolar zonas de possíveis desmoronamentos, bem como isolar intervalos que possam comprometer a continuidade da perfuração. Quando se trata de um poço de produção, o último revestimento denomina-se Revestimento de Produção, quando for o caso, o que permitirá os testes de produção do poço.

"Na perfuração rotativa as rochas são perfuradas pela ação da rotação e do peso aplicado a uma broca localizada na extremidade inferior de uma coluna de perfuração, a qual consiste basicamente de comandos de perfuração, de tubos de paredes espessas e de tubos de perfuração que são tubos de paredes finas. Os fragmentos de rochas ou cascalhos são removidos continuamente pelo fluido de perfuração (a lama). O fluido é injetado por bombas para o interior da coluna de perfuração por meio da cabeça de injeção (swivel) e retorna à superfície pelo espaço anular existente entre as paredes do poço e a coluna de perfuração" 5 .

5 - lbid, 2005 
Após o poço atingir uma determinada profundidade, havendo necessidade de troca de broca, a coluna de perfuração é retirada do poço e uma coluna de revestimento de tubos de aço, de diâmetro inferior ao da broca, é descida no poço. O espaço anular entre os tubos do revestimento e as paredes do poço é cimentado com a finalidade de isolar as formações atravessadas, permitindo o avanço da perfuração com segurança. Após a operação de cimentação, a coluna de perfuração é novamente descida no poço, tendo conectado à sua extremidade inferior uma nova broca de diâmetro menor do que a dos tubos de revestimento e prossegue-se a perfuração. Deste modo, mostra-se que um poço é perfurado em diversas etapas, caracterizadas pelos diferentes diâmetros de brocas.

\subsubsection{Sondas de Perfuração}

"Entende-se como sonda de perfuração, o conjunto de equipamentos, ferramentas e instrumentos necessários para a perfuração de um poço." ${ }^{\text {"6 }}$

A facilidade de compartimentação de uma sonda (desmembrar a sonda em partes) é característica especial no seu projeto, pois com freqüência a sonda deve ser desmontada, transportada e montada em outra locação. Deste modo, a portabilidade implica diretamente no tempo em que essas operações são executadas. O peso e a dimensão de cada equipamento são fatores importantes no projeto da sonda, e irão depender dos meios de transporte e das limitações e condições das estradas e rodovias que dão acesso às locações. 


\subsubsection{Tipos de Sonda}

As sondas podem ser classificadas em três tipos:

- Sondas Rotativas

- Mecânicas

- Diesel-elétricas

- Percussão

- Sondas Roto-pneumáticas

Em geral, os poços de petróleo são perfurados com sondas do tipo rotativas.

\subsubsection{Componentes da Sonda}

As sondas rotativas possuem os seguintes sistemas ditos principais: a - Sistema Motriz e Transmissões

A maioria das sondas existentes é equipada com motores diesel.

Com relação aos sistemas de geração de energia, as sondas podem ser classificadas em Sondas Mecânicas e Sondas Diesel-elétricas.

Nas Sondas Mecânicas a energia gerada pelos motores é transferida aos diversos componentes da sonda por meio de transmissão (Compound), constituída de embreagens, acoplamentos, eixos, correntes e engrenagens.

Sondas Diesel-elétricas são equipadas com geradores acionados por motor.

A Figura 07 mostra os Componentes de uma Sonda de Perfuração de Petróleo. 


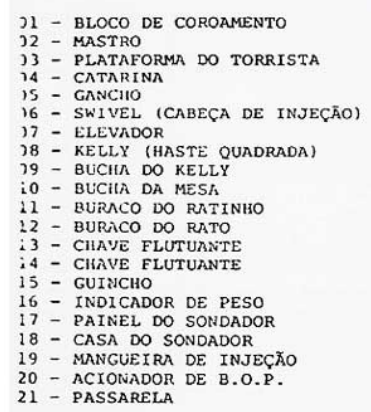

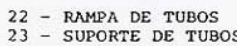

24 - SUB ESTRUTURA

26 - PENEIRA VIBRATORIA

27 - MANIFOLD
28 - SEPARADOR DE GAS DE LAMA

28 - SEPARADOR DE GAS

30 - DIQUE DE LAMA

- DTQUE DE LAMA

32 - DESSILTADOR

33 - DESAREIADOR

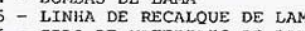

7 - CASA DE MATERIAIS DE LAMA

39 - TANQUES DE COMBUSTIVEL

41 - B.O.P. (VALVULA DE SE

ONADOR DE B.O.

- COTUNI DE PEPFURAÇÃO
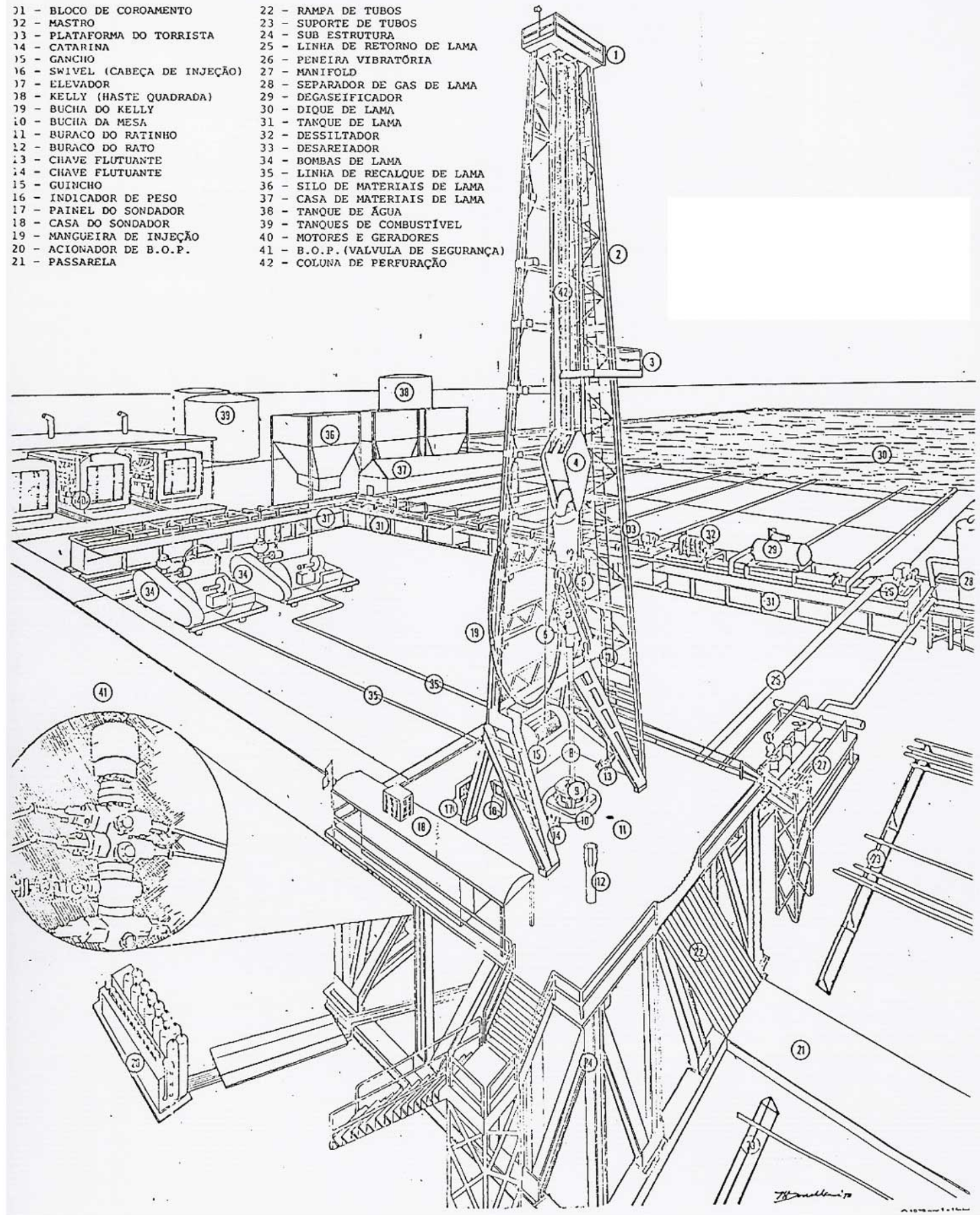

Figura 07 - Componentes de uma Sonda de Perfuração de Petróleo 
"Quatro tarefas essenciais são executadas nas operações de perfuração: 1) produzir e transmitir força; 2) sustentar e operar a coluna de perfuração, revestimento e tubos; 3) rodar a broca para fazer o furo e 4) bombear e circular lama para remover os fragmentos de rocha perfurada e manter estável ao poço." (INSITUTO, 1979).

A Figura 08 mostra a Vista Geral da Sonda de perfuração no Poço de Taciba - SP.

A maior parte da potência fornecida à sonda é consumida por duas operações, ou seja, para a circulação do fluido de perfuração (lama) e para as operações de manobras da coluna de perfuração. Esta potência é fornecida pelos motores e nas sondas diesel-elétricas pelos geradores de eletricidade.

As necessidades de potência variam de sonda para sonda, sendo que a maioria requer de $1.000 \mathrm{HP}$ a $3.000 \mathrm{HP}$ normalmente fornecidos por motores diesel pesados. Poços profundos estão sempre na classe de 3.000 HP.

"A energia é transmitida mecanicamente para um complexo que por sua vez é transmitido aos guinchos, mesa giratória e para as bombas de lama. Conversores de torque ou transmissão hidráulica são empregados nas sondas modernas. Unidades diesel-elétricas fornecem eletricidade aos cabos, aos redutores e aos motores elétricos ligados diretamente aos equipamentos (guinchos, mesa rotatória e bomba de lama)" (CONSÓRCIO, 1981b).

O guincho recebe a energia mecânica necessária para movimentação de cargas por meio da transmissão principal no caso das sondas diesel, ou indiretamente de um motor elétrico acoplado a ele nas sondas elétricas. 


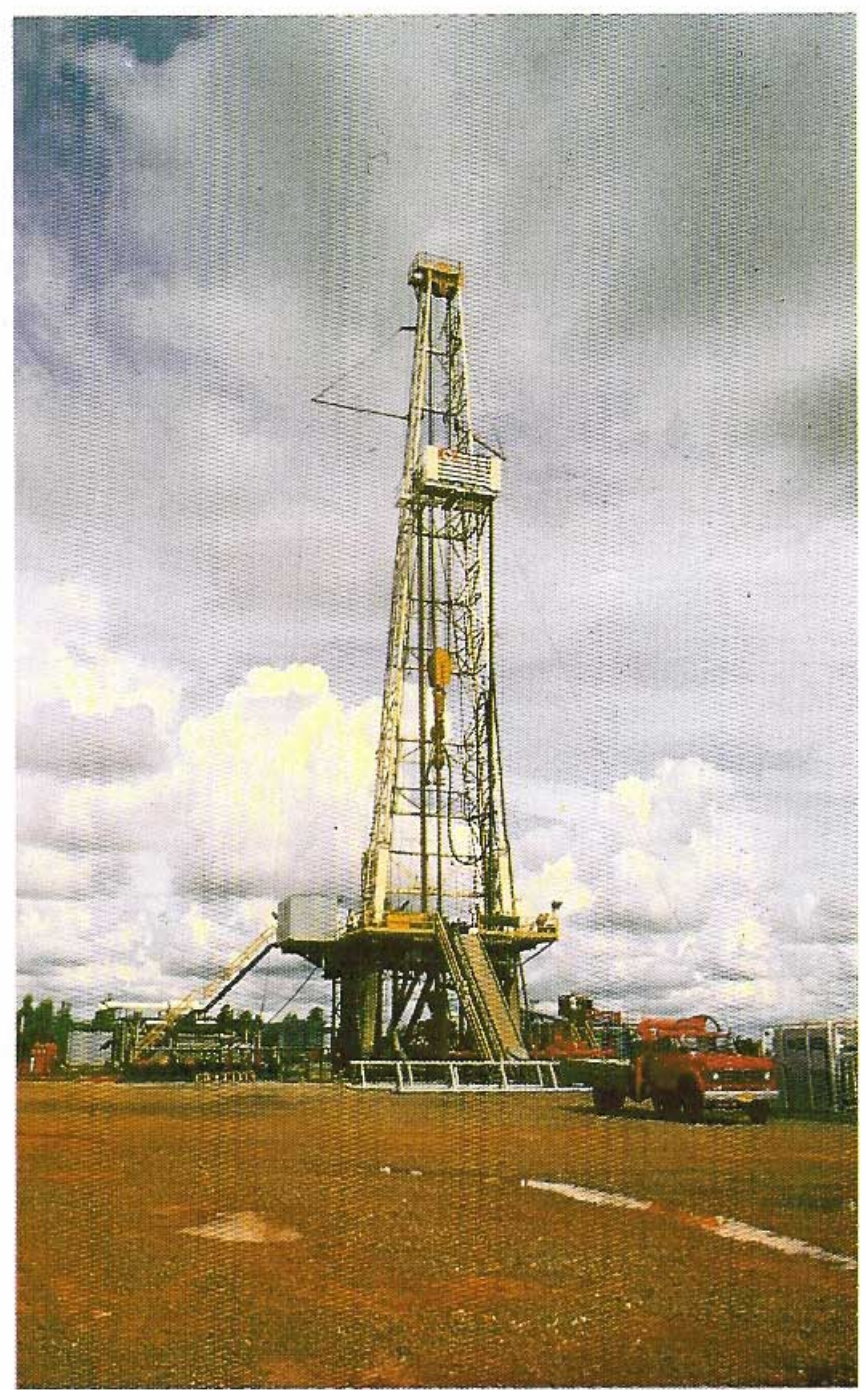

Figura 08 - Vista Geral da Sonda de perfuração no Poço de Taciba - SP 
A torre ou mastro é uma estrutura de aço especial, de forma piramidal, que permite prover um espaçamento vertical livre acima da plataforma de trabalho, para permitir a execução de manobras de descida e retirada da coluna de perfuração do poço e descida dos revestimentos.

b- Sistema de Rotação de Sonda

"Nas sondas convencionais, a coluna de perfuração é girada pela mesa rotativa situada na plataforma da sonda. A rotação, por meio de torque, é transmitida à coluna de perfuração e a broca conectada na extremidade inferior da coluna, por um tubo de parede externa poligonal normalmente chamado de haste quadrada ou "Kelly."

Um equipamento denominado Cabeça de Injeção (Swivel) separa os elementos rotativos daqueles estacionários na sonda de perfuração. Deste modo, sua parte superior não gira e sua parte inferior permite a rotação. $A$ cabeça de injeção é suspensa por uma alça de cabo de aço forjado acoplada ao gancho da sonda. O fluido de perfuração (a lama) é injetado no interior da coluna de perfuração, por meio da cabeça de injeção.

A haste quadrada (kelly) é um tubo especial, conectado na parte inferior da cabeça de injeção que é encaixada na bucha da rosca rotativa.

Existe também haste (kelly) com seção hexagonal que, em geral, é mais robusta, possuindo maior resistência à torção e flexão.

A principal função da mesa rotativa é transferir movimento de rotação (torque) à haste quadrada e à coluna de perfuração.

$7-$ lbid, 2005 
c- Coluna de Perfuração

Durante a perfuração é necessária a concentração de grande quantidade de energia na broca para cortar as diversas formações.

Esta energia em forma de rotação e peso aplicados sobre a broca é transferida às formações para prover a sua desagregação, formando pequenas lascas chamadas de cascalhos que são removidos do fundo do poço pelo fluido de perfuração (a lama).

Os poços profundos são perfurados com longas colunas de perfuração que podem superar 250 toneladas, constituídas de alguns tipos de tubos. Nas sondas maiores, a torre e o guincho em geral são dimensionados para suportar até 700 toneladas. $\mathrm{O}$ peso atuando sobre a broca é da ordem de algumas toneladas de tal modo que o guincho deve sustentar a coluna de perfuração durante todo o trabalho.

A coluna de perfuração é constituída de tubos especiais ocos, de aço sem costura, de comprimento em torno de 10 metros cada um.

Nas operações de manobra, onde a coluna de perfuração é retirada para diversas finalidades, como: trocar a broca, amostrar, e outras, a coluna é desarticulada sendo guardada em pé em segmentos de três tubos, ou seja, módulos máximos de 30 metros. Devido a esse fato há necessidade de altas torres que medem de 50 a 60 metros. Os tubos dão comprimento preciso à coluna e servem como condutor de lama ou fluido de perfuração.

Além dos tubos de perfuração, a coluna contém tubos pesados de aço forjado e usinado que tem como função principal, promover a transição entre os comandos e os tubos de perfuração, diminuindo a possibilidade de fadiga da 
coluna. Suas características principais são: menor espessura das paredes, conexões reforçadas, reforço central no corpo do tubo.

Comandos de Perfuração são tubos de aço forjado e laminado, que possuem alto peso linear, devido à grande espessura das paredes. Suas principais funções são prover peso sobre a broca e dar maior rigidez à coluna, permitindo assim, melhor controle da trajetória do poço.

As brocas são ferramentas que têm a função de promoverem a ruptura das formações. O estudo das brocas, considerando seu uso, desempenho e economicidade, é um dos principais fatores que influem no desempenho da perfuração.

Os estabilizadores são ferramentas projetadas para dar maior rigidez à coluna de perfuração. São posicionados, de acordo com as necessidades, nos trinta metros finais da coluna de perfuração. Em geral, possuem o mesmo diâmetro das brocas.

\subsubsection{Bombas de Lama}

No início da exploração de petróleo, o fluido de perfuração usado no resfriamento da sonda era a água. Ela era usada para "amaciar" a terra e facilitar a penetração da broca de perfuração.

Com o advento da sonda rotativa e das brocas cônicas, os fluidos de perfuração denominados "lamas", passaram a ser mais elaborados.

Basicamente a composição do fluido de perfuração (da lama) é uma mistura de material denso com a utilização de argilas especiais, barita ou produtos similares, água e óleo. 
Nas sondas convencionais são utilizadas pelo menos duas bombas de êmbolo.

O fluido de perfuração (a lama) é succionado dos tanques e recalcado no interior da coluna.

As principais funções do fluído de perfuração, ou seja, da lama são:

a- Resfriar a broca de perfuração, lubrificar seus dentes e remover os cascalhos entre os dentes da broca;

b- Resfriar a coluna de perfuração, absorvendo o calor gerado durante a operação de perfuração, liberando este calor por convecção e irradiação para o ar existente no entorno dos tanques na superfície;

c- Prover uma coluna hidrostática dentro do poço para contrabalançar as pressões das formações;

d- Remover para a superfície os cascalhos cortados pela broca;

e- Prover um reboco, ajudando a estabilizar as paredes do poço;

f- Possuir características que conseguem a boa qualidade dos perfis.

O caminho seguido pelo fluido de perfuração é o seguinte:

Após succionado pela bomba, passa pela mangueira rotativa e cabeça rotativa (swivel), passa pelo interior da haste quadrada (kelly), sendo injetado no interior da coluna de perfuração. O fluido de perfuração então retorna à superfície, passando pelos jatos da broca e entrando no espaço anular entre as paredes do poço e a coluna de perfuração. $\mathrm{O}$ fluido retorna aos tanques pela calha.

A calha conduz o fluido de perfuração até uma peneira vibratória, montada no topo de um dos tanques, chamado tanque de decantação. 
A peneira vibratória tem por finalidade separar do fluido de perfuração os cascalhos cortados pela broca e também as areias mais grossas. Depois, o fluido é tratado para voltar à circulação.

\subsubsection{Tanques de Lama}

São tanques de armazenamento e tratamento do fluido de perfuração. $O$ número de tanques varia de acordo com a capacidade da sonda de perfuração.

\subsubsection{Sistema de Segurança}

O equipamento básico de controle de pressão do poço fica abaixo do assoalho elevado da sonda e se constitui de uma complexa e maciça válvula de "blowout" ("blowout preventer").

O "preventer" permite o fechamento do espaço anular do poço de perfuração. É acionado para impedir ou controlar a saída desordenada de fluidos (gás ou líquido) das formações geológicas perfuradas. A saída não controlada de fluidos é um risco enorme para a sonda, pessoas, equipamentos

e pode levar a gigantescos incêndios, que chegam a prejudicar a potencialidade da jazida.

"Durante a rotina de perfuração, o poço deve ser sempre mantido cheio de lama de modo a manter a máxima pressão hidrostática nas formações atravessadas, minimizando os risco de "blowout."' (CONSÓRCIO, 1981a). 


\subsubsection{Sistemas de Monitoramento de Perfuração de Poços}

O monitoramento da perfuração de um poço é feito por meio de equipamentos e instrumentos necessários ao controle da perfuração, dos quais os principais são: manômetro, indicador de peso sobre a broca, indicador de torque, tacômetro e outros.

"Com o progresso da perfuração, observou-se que para se atingir o máximo de eficácia e economia, seria necessário uma perfeita coordenação entre os vários parâmetros de perfuração. Assim, surgia a necessidade do uso de equipamentos e instrumentos para o registro e controle destes parâmetros."8

Os principais indicadores são:

- indicador de peso no gancho e sobre a broca;

- o manômetro que indica a pressão de bombeio;

- o torquímetro para o torque na coluna de perfuração;

- o tacômetro para medir as velocidades da mesa rotativa e das bombas de lama.

O registrador mais importante é o que mostra a taxa de penetração da broca, que é uma informação importante para se avaliar as mudanças das formações perfuradas, o desgaste das brocas e adequação dos parâmetros de perfuração.

\subsection{Perfuração a ar}

“A Bacia do Paraná se caracteriza pela existência de uma espessa camada de basalto que chega a atingir até 1700 metros. Quando da perfuração dos poços estratigráficos pelo sistema convencional, foi constatado que os 
avanços das perfurações foram insatisfatórios, levando à análise de alternativas possíveis para redução do tempo de perfuração. Umas das alternativas consideradas foi a da utilização do sistema de perfuração a ar, reconhecidamente mais rápido que a perfuração no sistema convencional. Visando a utilização do sistema a ar, foi contratada, por 45 dias empresa especializada para realizar uma primeira experiência com o sistema de perfuração a ar ("air drilling") de forma pioneira na Bacia do Paraná. A perfuração de basaltos com o sistema da injeção de ar foi realizada no Poço 1 - CS - 2 - PR (Chapéu do Sol no 2) e a de sedimentos no Poço 3 - CB - 4 - SP (Cuiabá Paulista n 4)" (CONSÓRCIO, 1981c).

Após a perfuração programada, a avaliação do sistema a ar concluiu que comparativamente ao sistema convencional a perfuração a ar, em basaltos e sedimentos contendo pouco volume de água, mostrou a viabilidade técnicaeconômica da utilização do sistema a ar na Bacia do Paraná.

Sob o ponto de vista de aplicabilidade o sistema de perfuração a ar pode ser utilizado tanto em basaltos como em sedimentos, à exceção das formações Botucatu e Rio do Rasto para intervalos onde ocorra excessivo volume de água de formação.

Nos casos de aplicação não apresenta nenhuma limitação para se passar ao sistema convencional com lama ou vice-versa.

\subsection{Serviços Associados à Perfuração de Poços}

$\mathrm{Na}$ perfuração de poços de hidrocarbonetos, existe uma gama de serviços associados, que compreendem basicamente: 
Programa de brocas, revestimentos, engenharia de suprimento de lama, testemunhagem e análise dos testemunhos, serviços de perfilagem, avaliação das formações, colocação de revestimento, cimentação, serviços de completação, perfuração e canhoneamento das formações e fraturamento.

\subsubsection{Programa de Brocas}

As companhias fornecedoras de brocas possuem arquivos de poços perfurados e estão aptas a recomendar um programa de brocas para a maioria das seções geológicas do mundo. O programa do poço é analisado e as melhores brocas adaptadas para as formações a serem perfuradas são cuidadosamente selecionadas.

No caso da Bacia do Paraná, existem bacias sedimentares semelhantes, e que são produtoras, como, por exemplo, nos Estados Unidos e na Rússia. A coluna estratigráfica típica da Bacia do Paraná, já conhecida, permitiu ao Consórcio CESP/IPT estabelecer programa de brocas para a perfuração de seus poços.

A Figura 09 mostra a Coluna Estratigráfica da Bacia do Paraná.

Em um poço padrão perfurado pelo Consórcio CESP/IPT na Bacia do Paraná, o programa inicial de brocas adotado pela engenharia de perfuração foi o seguinte:

\begin{tabular}{|c|c|}
\hline Intervalo (m) & $\emptyset$ de perfuração (pol) \\
\hline $0-220$ & 26 \\
\hline $220-400$ & $171 / 2$ \\
\hline $400-3000$ & $121 / 4$ \\
\hline $3000-4000$ & $81 / 2$ \\
\hline
\end{tabular}




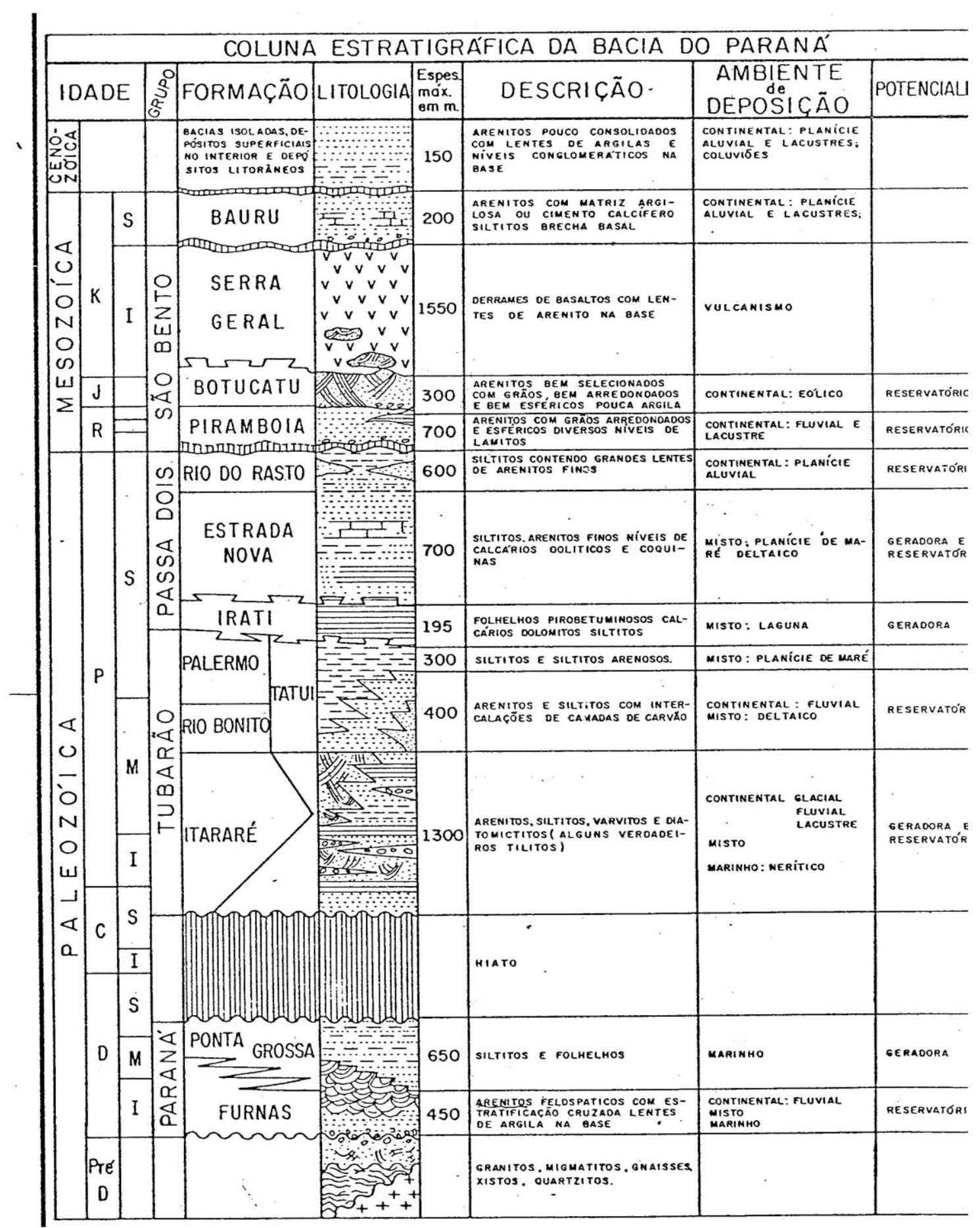

Figura 09 - Coluna Estratigráfica da Bacia do Paraná.

Fonte: Consórcio CESP/IPT - Geologia da Bacia do Paraná - Reavaliação da Potencialidade e Prospectividade em Hidrocarbonetos. São Paulo. 1982. 
Considerando as peculiaridades de cada poço perfurado, este programa foi sendo adaptado para as perfurações subseqüentes.

Como as camadas estratigráficas da Bacia do Paraná possuem grandes derrames de basalto, chegando a 1.700 metros de espessura em alguns poços perfurados, o Consórcio CESP/IPT utilizou, além de brocas para formações moles, brocas especiais para furar as formações duras como o basalto e 0 diabásio.

Pode-se classificar as brocas utilizadas nas perfurações do Consórcio CESP/IPT, de uma forma simplificada, em dois grandes grupos: brocas com dentes de aço, denominadas "brocas convencionais"; e brocas "journal" com insertos de tungstênio, denominadas "brocas especiais".

"Durante a perfuração de um poço de petróleo, em relação às brocas, os seguintes fatores são primordiais no seu programa de utilização: custo da broca; durabilidade da broca durante a perfuração; tempo de manobra para a troca ou substituição da broca; a profundidade da troca da broca; e, especialmente, o sistema de recondicionamento da lama, operação de retirar da lama as partículas de rocha cortada pela broca, evitando ao máximo, a recirculação de lama carregada de partículas abrasivas, que vão provocar desgaste nos dentes da broca, diminuindo a sua durabilidade." (GALHANO et al, 2006b).

Quando se interrompe a perfuração de um poço para a troca de sua broca, a empresa paga as horas paradas pela sonda, o que custa caro, e quanto mais profunda a perfuração, mais horas a sonda fica parada.

Por outro lado, as brocas especiais duram mais tempo de trabalho, principalmente nas formações duras, do que as brocas convencionais. 
Um estudo do Consórcio CESP/IPT mostrou a média de horas paradas durante o tempo de manobra de uma sonda para a troca de brocas, num poço de 4.000 metros, como a seguir:

\section{Profundidade do Poço (m)}

250

1000

2000

3000

4000

\section{Tempo de Manobra (h)}

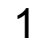

4

8

12

16

Fonte: Consórcio CESP/IPT - Relatório de Materiais - Programa de Brocas - São Paulo. 1981c.

Portanto, no estudo de um programa de brocas, para a perfuração de um poço, existem várias considerações a serem feitas.

Em geral, as "brocas convencionais" são usadas para perfurar as camadas mais "moles", enquanto que as "brocas especiais", as mais "duras". Entretanto, a combinação de brocas deve considerar também as profundidades das trocas e o custo das brocas.

Considerando todas essas variáveis, o Consórcio CESP/IPT, no seu programa de brocas, em relação aos seus estoques, utilizou $83,19 \%$ das brocas especiais e $45,52 \%$ das brocas convencionais.

Com resultados obtidos durante a execução do programa de perfuração do Consórcio CESP/IPT, um estudo revelou que, apesar das brocas especiais custarem cerca de 2,75 vezes mais do que as convencionais, o custo total de sua utilização é cerca de 3,3 vezes menor, motivo pelo qual deu-se preferência à utilização de brocas especiais.

O Consórcio CESP/IPT desenvolveu um eficaz programa de manutenção e recuperação de brocas usadas visando a sua reutilização, realizado para os dois tipos de brocas, como se segue: 


\section{a) Brocas Convencionais:}

Após a retirada do poço, era analisado o seu desgaste; e se reutilizável, era emergida em água durante 24 horas, para soltar os resíduos de lama dos rolamentos. Depois, era emergida em banho de óleo por 12 horas, girando os cones de vez em quando, para manter os rolamentos devidamente protegidos contra a corrosão. Finalmente, passava-se graxa nos cones, pintando-as com o novo código de reutilização; e

\section{b) Brocas Especiais (Tipo "Journal"):}

Estas possuem rolamentos selados. Após a retirada do poço, era analisado o seu desgaste, e sendo reutilizável, era bem limpa, removendo-se todos os resíduos de lama. Depois, era pintado seu corpo e codificada para reutilização. Estas brocas não devem ser imergidas em óleo, para não estragar o anel de borracha da vedação.

A Figura 10 mostra a Vista do depósito de brocas de perfuração e de tubos de revestimentos, do consórcio CESP/IPT em Bauru - SP.

A Figura 11 mostra as Brocas de perfuração de petróleo. 


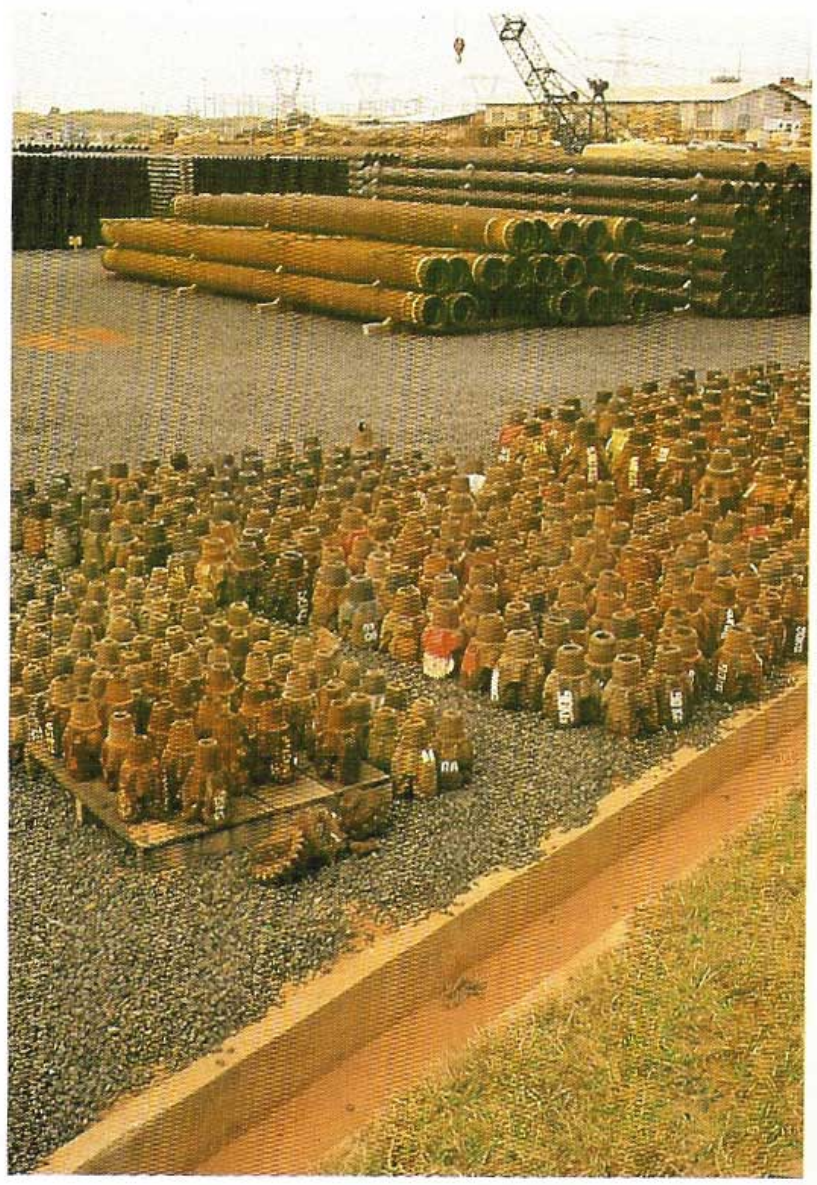

Figura 10 - Vista do depósito de brocas de perfuração e de tubos de revestimentos, do consórcio CESP/IPT em Bauru - SP 

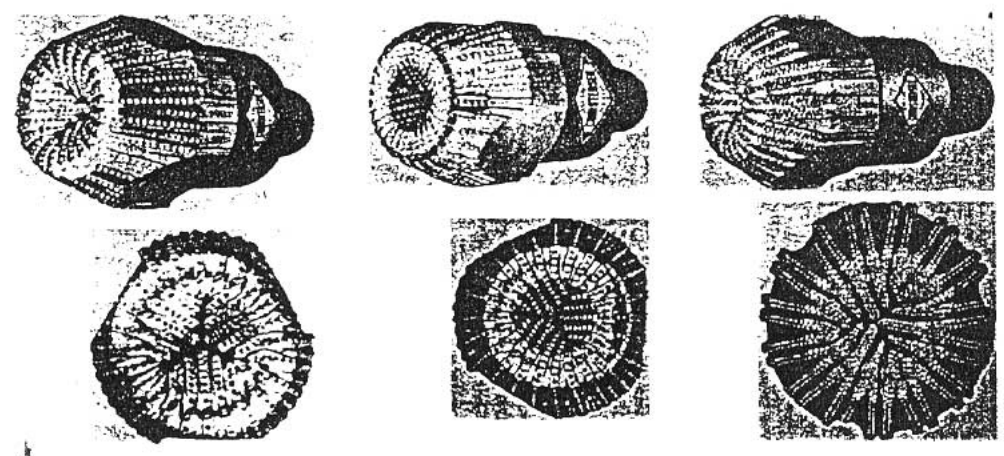

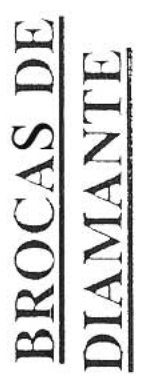

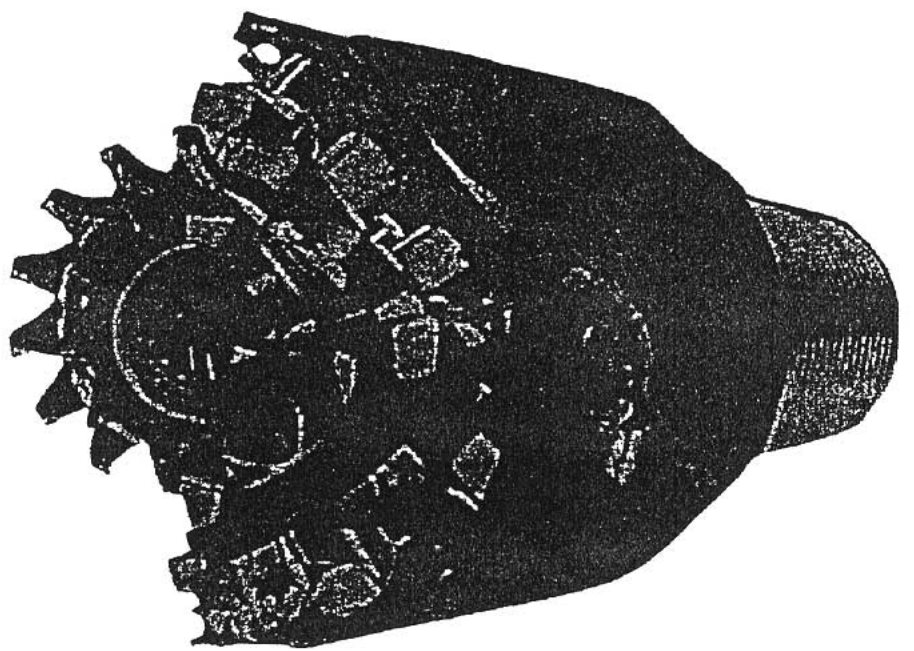

$\mid$
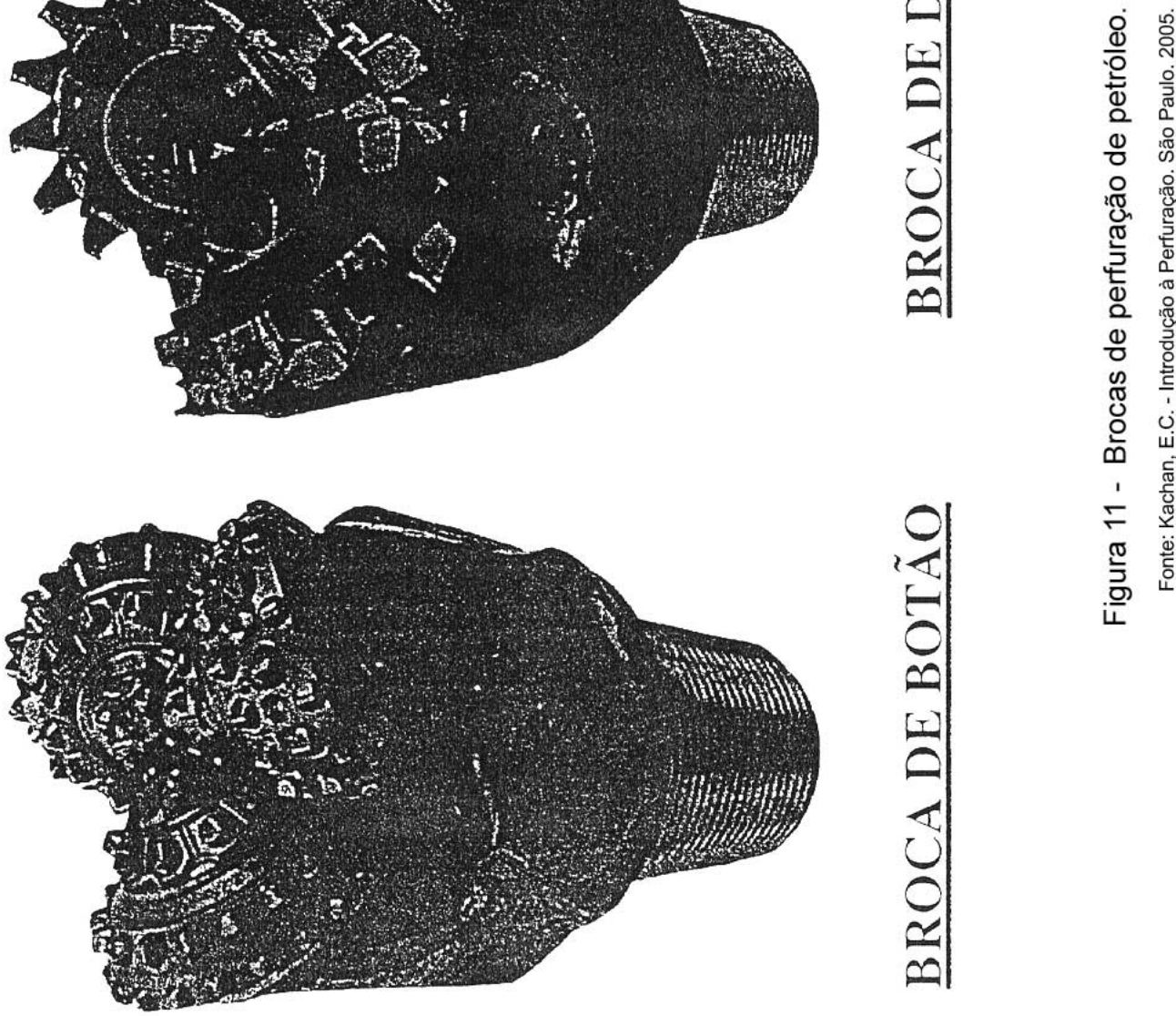


\subsubsection{Perfilagem e Testes de Formações}

Num processo de pesquisa geológica de uma bacia sedimentar, como a Bacia do Paraná, a perfuração de um poço para petróleo representa a fase de exploração direta.

Para se conseguir uma definição da potencialidade de um determinado poço, no que concerne a produção de hidrocarbonetos, foi utilizada uma metodologia que de forma geral é chamada de Avaliação de Formações.

Por meio deste método, foram coletados testemunhos e amostras de calha, foram corridos perfis elétricos, foram realizados testes de formação e ainda foram mantidos registros contínuos das características do fluido de perfuração como ocorrência de gás, óleo e água, e da taxa de penetração.

"De acordo com esses dados, permitiu-se definir outros:

- porosidade e permeabilidade de reservatórios;

- intervalos portadores de hidrocarbonetos;quantidade relativa dos fluidos contidos nos poros (água, gás e óleo);

- estimativas de reservas;

- capacidade de produção de um reservatório / poço." (CONSÓRCIO, 1982c).

\subsubsection{Perfilagem ("Well Logging”)}

Considera-se que a perfilagem é a mais eficaz ferramenta disponível, para a avaliação de um poço. 
A perfilagem tornou-se prática internacional, cada vez mais utilizada, na perfuração ininterrupta de um poço até a sua profundidade final e somente avaliá-lo por meio das análises de perfis.

"Uma sonda conectada à superfície, por meio de um cabo elétrico, multicondutor, registra continuamente as características das formações atravessadas pelo poço, e que podem ser relacionadas a uma determinada propriedade física das rochas." (SIMON et al, 1982).

O Consórcio CESP / IPT utilizou rotineiramente nas operações de perfilagem de seus poços as experiências das mais reconhecidas empresas de perfilagem.

As companhias que trabalharam para o Consórcio CESP/IPT estavam capacitadas para executar perfilagem em poços de até $6.000 \mathrm{~m}$ de profundidade, e suas unidades de superfície contaram com computadores para o processamento, sendo que os dados obtidos foram registrados em fitas magnéticas e filmes ópticos copiativos.

A Figura 12 mostra o Esquema de uma Operação de Perfilagem. 


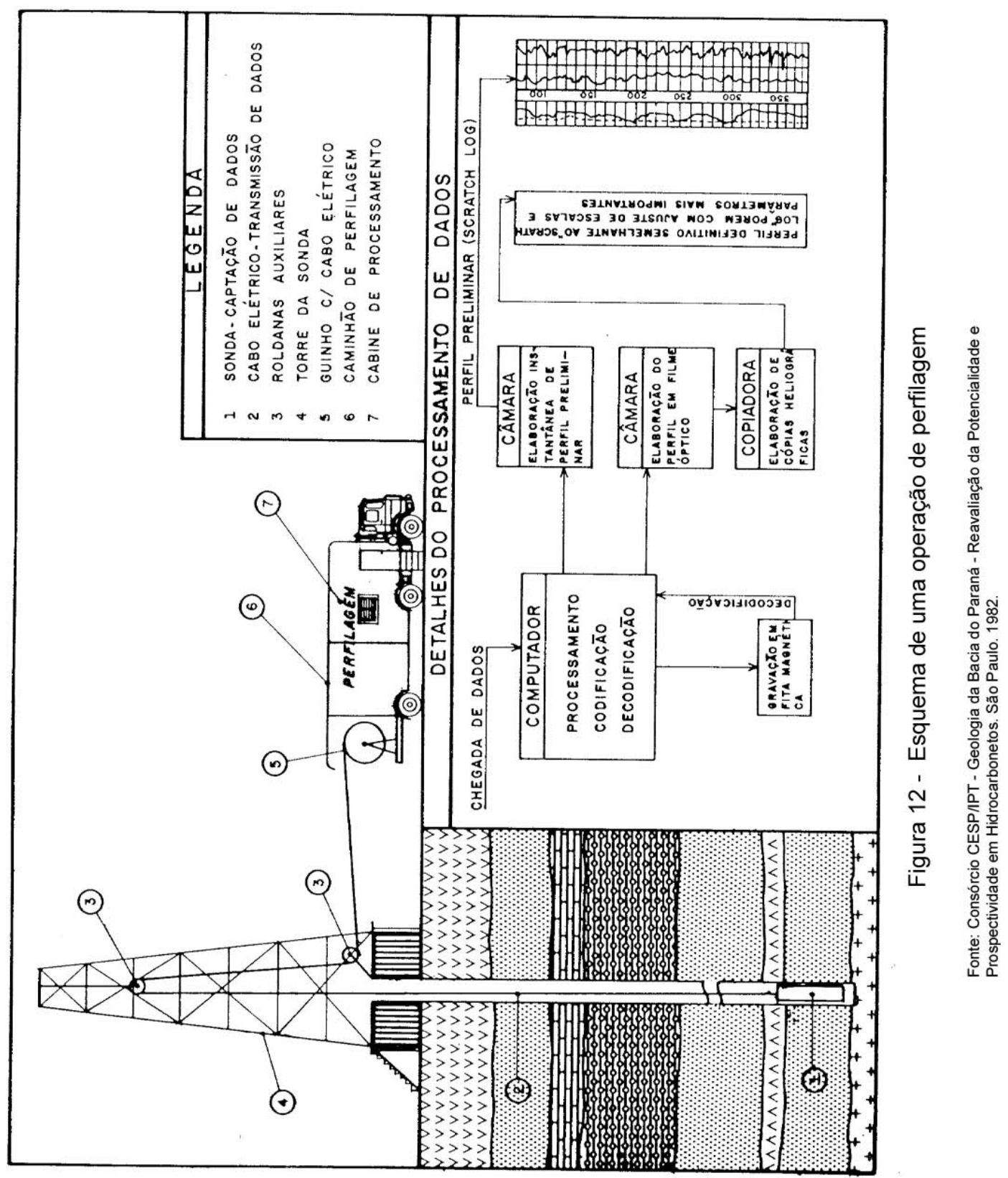


"Em um programa de perfilagem padrão, foram corridos os seguintes perfis:

- perfil de resistividade (indução, dupla-indução, laterolog ou indução esférica);

- perfil sônico;

- perfil raios gama;

- perfil densidade;

- perfil neutrão;

- perfil de mergulho;

- perfil sísmico.

No caso de necessidade de detalhamento de zonas de interesse ou para obtenção de outras informações complementares, o equipamento ainda dispõe de:

- perfil de micro-resistividade;

- perfil de lito densidade;

- perfil de diâmetro do poço;

- testador de formação respectiva;

- ferramenta de amostragem lateral." (SIMON et al, 1982).

A profundidade das rochas das formações perfuradas foi medida por meio dos perfis sônicos, densidade e neutrão.

A resistividade dessas rochas foi medida pelos perfis indução e duplaindução.

Com estes dados e por meio de fórmulas específicas, calcularam-se as saturações dos diversos fluidos, contidos nos poros das rochas. 
O perfil de raios gama foi extensivamente utilizado para definir a litologia e individualizá-la.

Para conhecer a atitude (direção e mergulho) das diversas feições sedimentares, tais como: estratificações cruzadas, mergulhos regionais e outros, foi utilizado o perfil de mergulho.

Utilizando o perfil sísmico conseguiu-se a construção de sismogramas sintéticos locais, como também, identificar refletores abaixo da profundidade final do poço, e a obtenção do VSP ("vertical sismic profile"), imprescindível para distinguir nas seções sísmicas entre refletores primários e múltiplos, permitindo ainda, a exata localização do refletor por meio da transformação tempo x profundidade.

"No período compreendido entre 1980 e 1982, de um total de 27 poços perfurados pelo Consórcio CESP/IPT, na Bacia do Paraná, foram corridos cerca de $672.000 \mathrm{~m}$ de perfis." (SIMON et al, 1982).

\subsection{Registro Contínuo das Características do Fluído de Perfuração ("Mud Logging")}

O registro dos dados de perfuração é a forma mais antiga de coleta de informação de um poço.

A Figura 13 ilustra o Esquema de "Mud Logging", onde basicamente examinou-se e registrou-se, em função da profundidade, dado sobre a taxa de perfuração (lama) por gás/óleo/água e descreveram-se cuidadosamente as amostras de calha. 


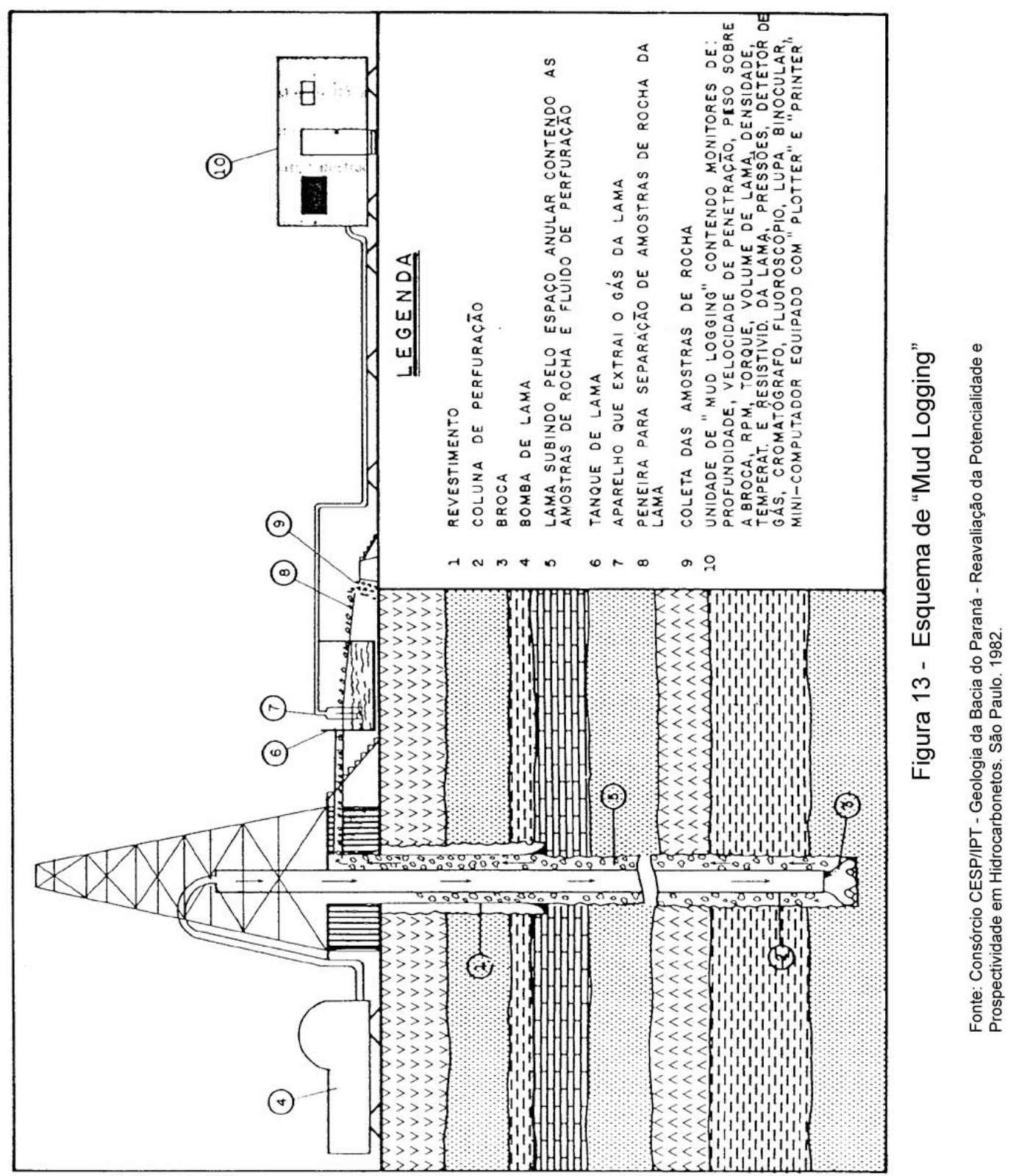


"O Consórcio CESP/IPT teve à sua disposição equipamentos altamente sofisticados, onde foi possível automaticamente e criticamente a monitoração dos seguintes parâmetros de perfuração:

- profundidade;

- velocidade de penetração;

- peso sobre a broca;

- rotações por minuto da broca;

- torque na coluna de perfuração;

- volume de lama nos tanques;

- densidade, temperatura e resistividade da lama (entrada e saída);

- pressão de injeção das bombas de lama;

- pressão interna do revestimento." (SIMON et al, 1982).

No que tange às anomalias de gás foi feito um registro contínuo durante a perfuração tendo sido ainda possível, por meio de cromatógrafos, analisar-se quantitativamente a composição do gás, desde a fração metano até pentano.

Os testemunhos e amostras de calha foram descritos em lupas binoculares, com capacidade de aumento de até 40 vezes, e ainda foram examinadas em fluoroscópio, para a verificação da presença de hidrocarbonetos.

O Consórcio CESP/IPT se utilizou de 4 unidades completas de "mud logging". 


\subsubsection{Testes de Formações}

O objetivo da realização de um teste de formação é o de colocar-se, por períodos de tempo variáveis, um poço em produção de forma controlada.

A Figura 14, Esquema de Teste de Formação, mostra como funciona um teste de formação:

"Por meio da interpretação dos dados gerados pelo teste, determinamse: a vazão do poço, as pressões do reservatório, a área drenada durante o teste, a permeabilidade do intervalo testado, se o mesmo foi danificado durante o processo de perfuração." (SIMON et al, 1982).

Devido à importância do conhecimento hidrodinâmico da Bacia Paraná, foram efetuados testes, independentemente da presença de indícios de hidrocarbonetos, apenas para a coleta de água de formação e conhecimento das pressões dos reservatórios.

"No período de junho/80 a agosto/82, em 27 poços perfurados, foram executados pelo Consórcio CESP/IPT um total de 151 testes de formação, com um índice de sucesso global de $67 \%$. Os testes foram executados a poço aberto, em diâmetro de 81/2" e 91/4" e em revestimentos de 51/2" e 95/8". O teste mais profundo, a poço aberto, foi realizado no poço $2-\mathrm{Na}-1-\mathrm{PR}$ (Altônia) a profundidade de 5070,0 metros." (SIMON et al, 1982).

Para execução destes testes, o Consórcio CESP/IPT contou com os serviços de duas empresas internacionais, capacitadas a realizar testes em poço aberto revestido e a profundidades superiores a 6000 metros. 


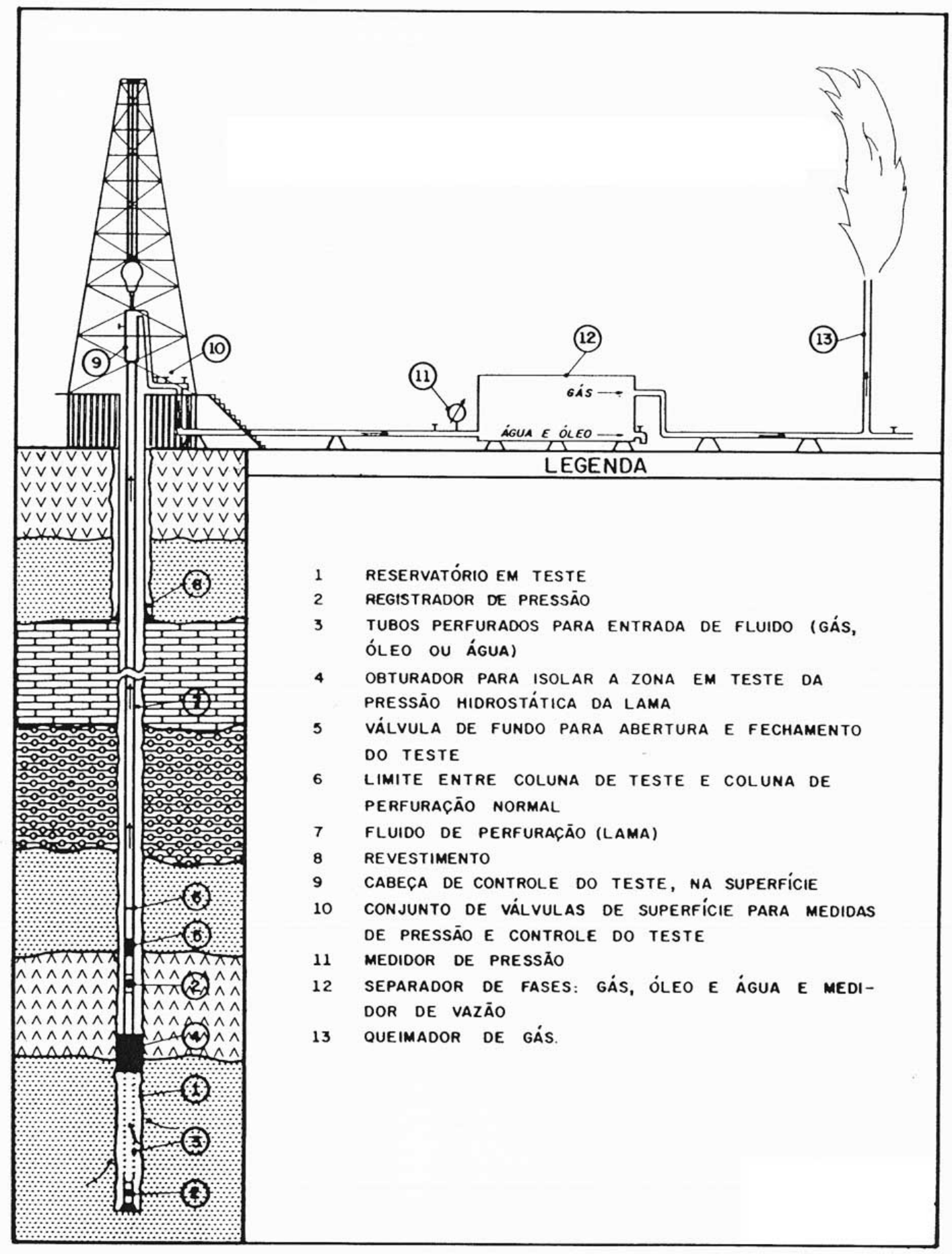

Figura 14 - Esquema de um Teste de Formação

Fonte: Consórcio CESP/IPT - Geologia da Bacia do Paraná - Reavaliação da Potencialidade e Prospectividade em Hidrocarbonetos. São Paulo. 1982. 
Normalmente, os testes de formação são realizados em duas situações distintas:

- a primeira refere-se aos testes a poço aberto, durante a perfuração, principalmente para avaliar indícios de hidrocarbonetos.

- A segunda, aos testes a poço revestido, após a conclusão do poço.

Para ambos os casos foram usadas duas interpretações distintas:

A primeira é uma interpretação preliminar, qualitativa e tem por principal finalidade, diagnosticar a conclusividade ou não dos testes e, assim decidir-se pela próxima operação da sonda.

A Figura 15 apresenta um exemplo real de uma Carta de Pressão de um Teste de Formação por Coluna, do Poço 2 - CS - 1 - PR (Chapéu do Sol).

"A interpretação qualitativa das cartas de pressão, aliada à análise do fluído recuperado (gás e/ou óleo e/ou água), permite chegar a dados também qualitativos sobre permeabilidade, transmissibilidade, perda de pressão do reservatório (depleção) e dano de formação. Este tipo de análise foi feito obrigatoriamente para todos os testes, no próprio poço. 


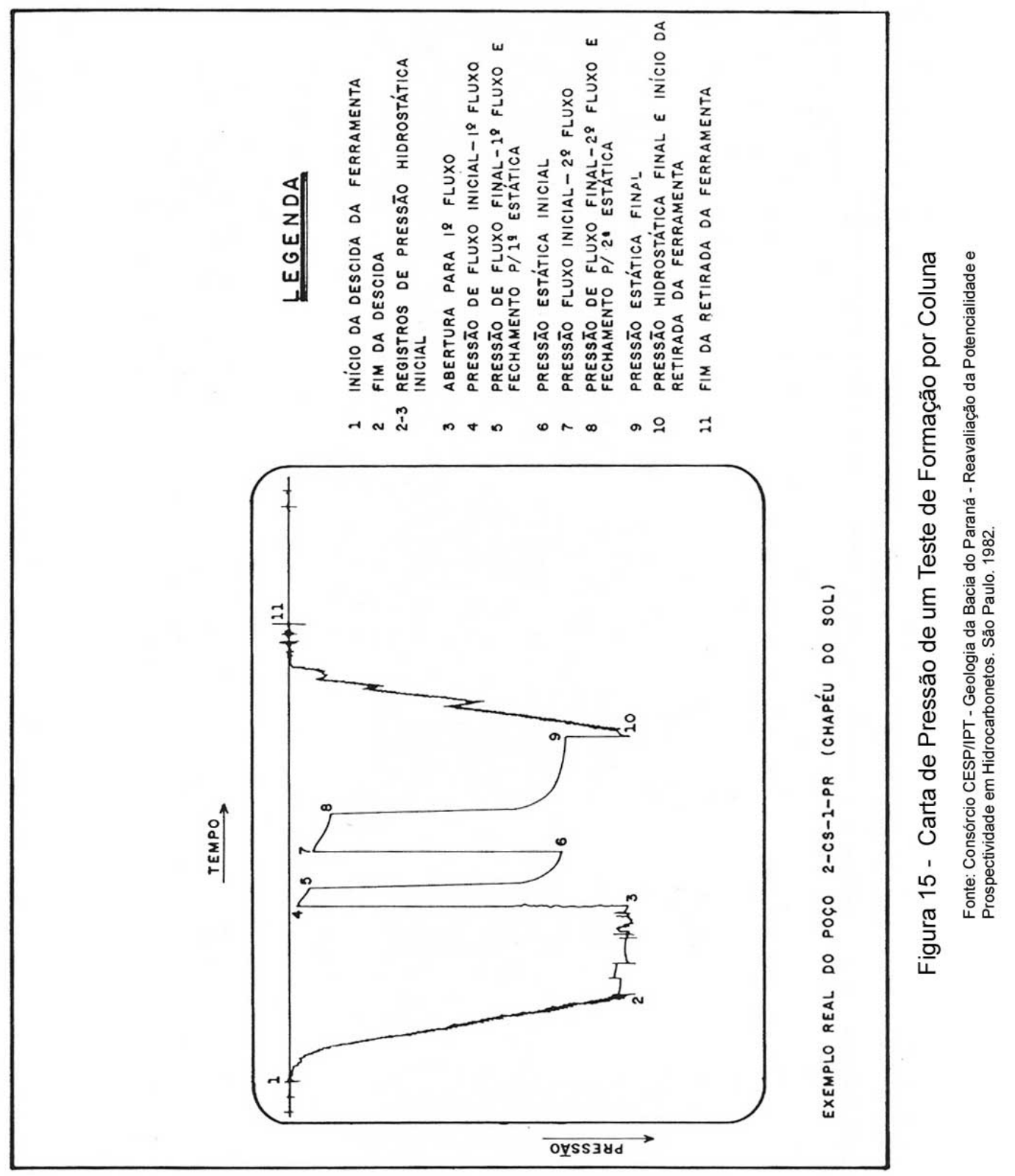


Após análise qualitativa foram selecionados alguns testes, que oferecem condição para análise quantitativa, que permitiu definir os seguintes parâmetros:

- vazão;

- permeabilidade;

- razão do dano de formação;

- índice de produtividade;

- capacidade teórica de produção;

- superfície potenciométrica;

- vazão teórica máxima;

- vazão teórica mínima." (SIMON et al, 1982).

A leitura das cartas de pressão foi feita normalmente no escritório, com um micrômetro que possuía precisão de milésimos de polegada, obtendo-se assim todo o desenvolvimento do teste em termos de pressão $\mathrm{X}$ tempo.

"Dentre os métodos de interpretação utilizados internacionalmente, para testes de líquidos (água ou óleo), o mais usado é o Método Horner (1951) que usa como base a equação da difusibilidade, que visa investigar o crescimento de pressão após o fechamento do poço, próximo ao fundo, após um período de fluxo (caso dos testes de formação de curta duração), sendo a equação:

$$
P c=P e-\frac{162,6 \times Q \times \mu \times B}{K h} X \log _{10} \frac{t+\theta}{\theta}
$$

onde:

$\mathrm{Pc}=$ pressão de confinamento, num tempo de fechamento, após o fluxo (psi).

$\mathrm{Pe}=$ pressão estática da formação ou pressão máxima do reservatório (psi).

$\mathrm{Q}=$ produção diária estimada (bbl/dia). 
$M=$ viscosidade de fluído (cp).

$B=$ fator volumétrico de formação.

$\mathrm{K}=$ permeabilidade efetiva $(\mathrm{mD})$.

$h=$ intervalo permeável (pés).

$t=$ tempo de fluxo (minutos).

$\Theta=$ tempo de confinamento num determinado ponto de Pc (minutos)." (SIMON et al, 1982).

Todos os demais parâmetros do intervalo testado (permeabilidade, dano) foram obtidos analiticamente por meio de fórmulas apropriadas. Para poços de gás, é igualmente aplicado o método Horner com algumas modificações.

Em casos especiais o Consórcio CESP/IPT utilizou computadores para o processamento dos dados do teste, bem como utilizou análises mais sofisticadas, como por exemplo, as curvas tipo (Gringerteu -1979)." (SIMON et al, 1982). 


\section{O POÇO DE CUIABÁ PAULISTA (POÇO 2 - CB - 1 - SP)}

A Figura 16 - Mapa Esquemático de Situação do Poço 2 - CB -1 Cuiabá Paulista - SP, mostra a localização do Poço no oeste do Estado de São Paulo, numa região chamada de Pontal do Paranapanema.

A Figura 17 - Mapa Esquemático de Localização e Acesso do Poço 2 CB - 1 - Cuiabá Paulista - SP ilustra a forma de acesso para chegar até a localidade do poço.

\section{Resultados Obtidos}

"Os resultados de gás obtidos em Cuiabá Paulista evidenciaram a potenciabilidade petrolífera da Bacia do Paraná. Locado no plano invertido de uma anomalia morfoestrutural, o poço $2-\mathrm{CB}-1$ - SP, após atravessar uma soleira de diabásio de 144 metros de espessura, atingiu uma seção arenosa da parte basal da Formação Itararé, portando hidrocarbonetos leves. Estes arenitos se apresentam com uma espessura de 374 metros, imediatamente sobrepostos, por discordância, aos folhelhos da Formação Ponta Grossa.

Por meio de interpretação de perfis e análise dos testes de formação, a poço aberto e revestido, foi possível identificar cinco zonas portadoras de gás:

1) Intervalo $4.601,5$ - 4.630 metros; arenito com porosidade média de $9,3 \%$ e saturação d'água de $39 \%$, permeabilidade de $0,31 \mathrm{mD}$ e "net gás pay" de 17,5 metros.

Com um dano de formação de 3,89 , este intervalo mostrou uma vazão de $51.000 \mathrm{~m}^{3} / \mathrm{dia}$ 


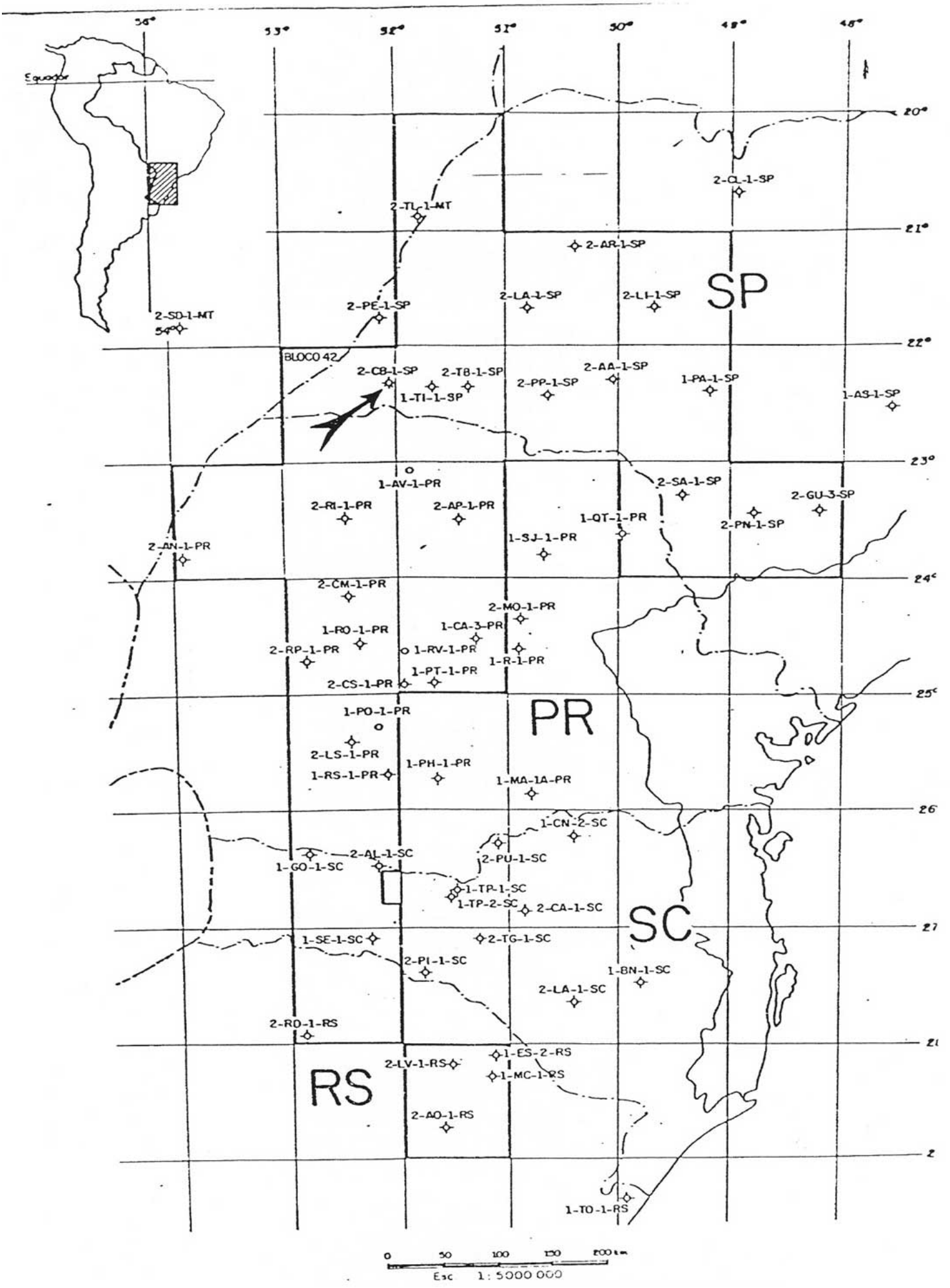

Figura 16 - Mapa Esquemático de Situação do Poço 2-CB-1 - Cuiabá Paulista - SP 


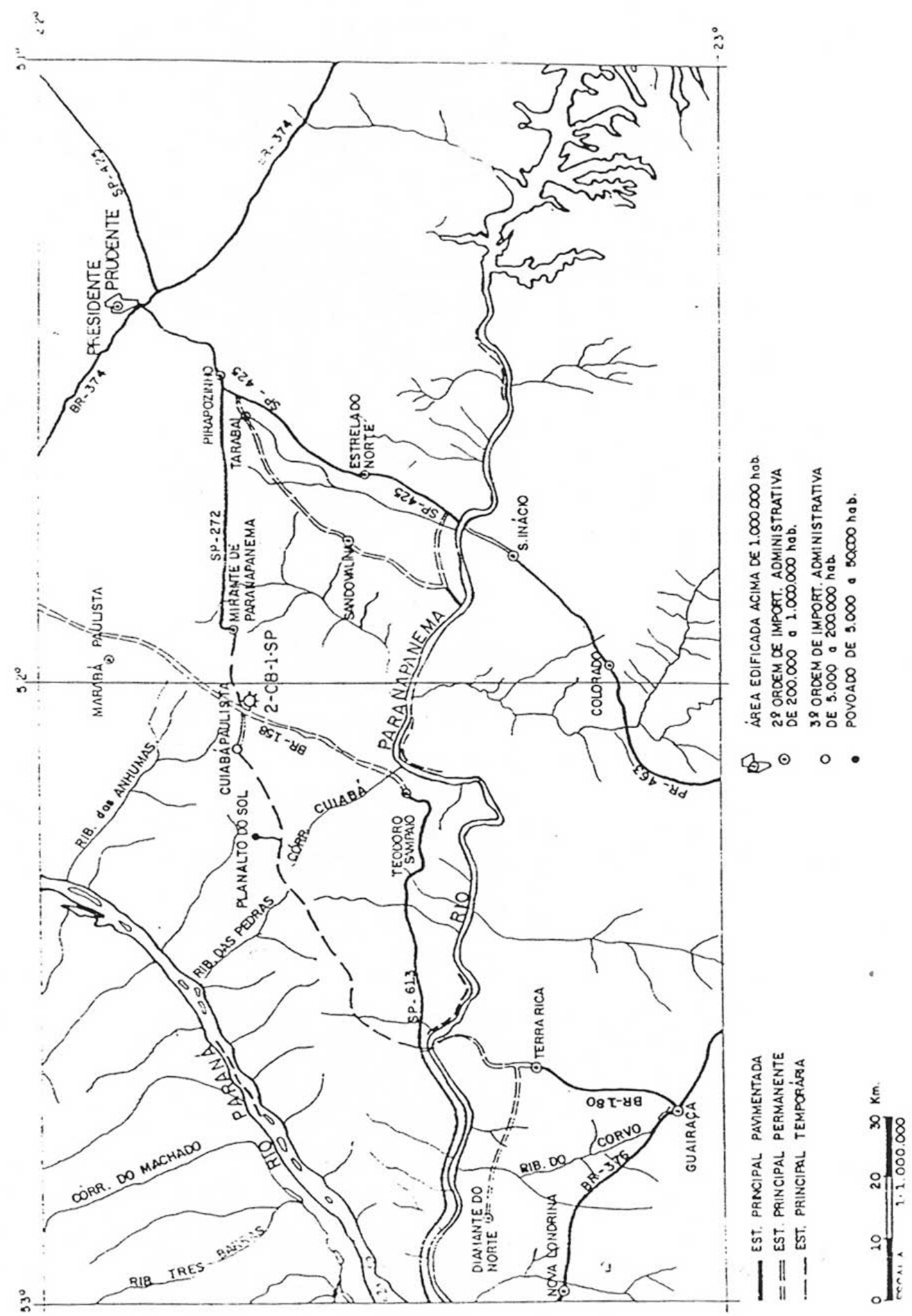

Figura 17 - Mapa Esquemático de Localização e Acesso do Poço 2-CB-1 - Cuiabá Paulista - SP

Fonte: Consórcio CESP/IPT - Relatório do Poço Estratigráfico de Cuiabá Paulista. São Paulo. 1982. 
2) Intervalo 4.582 - 4.595 metros; diabásio fraturado que em testes de produção, a poço revestido, mostrou uma vazão estabilizada de 21.000 $\mathrm{m}^{3} /$ dia de gás;

3) Intervalos $4.418-4.428$ metros, $4.452-4.458$ metros e $4.540-4522$ metros, que apresentaram características em perfis de diabásio fraturado com gás.

A Figura 18 apresenta a Litoestratigrafia constatada no Poço 2-CB-1 Cuiabá Paulista - SP.

O Poço de Cuiabá Paulista foi locado com base em dados de superfície, uma vez que seu objetivo inicial era estratigráfico, para melhor caracterizar a coluna litológica no centro da Bacia do Paraná.

Este poço estratigráfico foi locado numa anomalia de drenagem obtida a partir de interpretação de imagens de radar e satélite.

A Figura 19 mostra o Esquema de perfuração do Poço 2-CB-1 - Cuiabá Paulista - SP.

A Figura 20 mostra o Posicionamento esquemático dos testes do Poço 2-CB-1 - Cuiabá Paulista - SP.

A Figura 21 mostra o Teste de formação do Poço 2-CB-1 - Cuiabá Paulista - SP. 


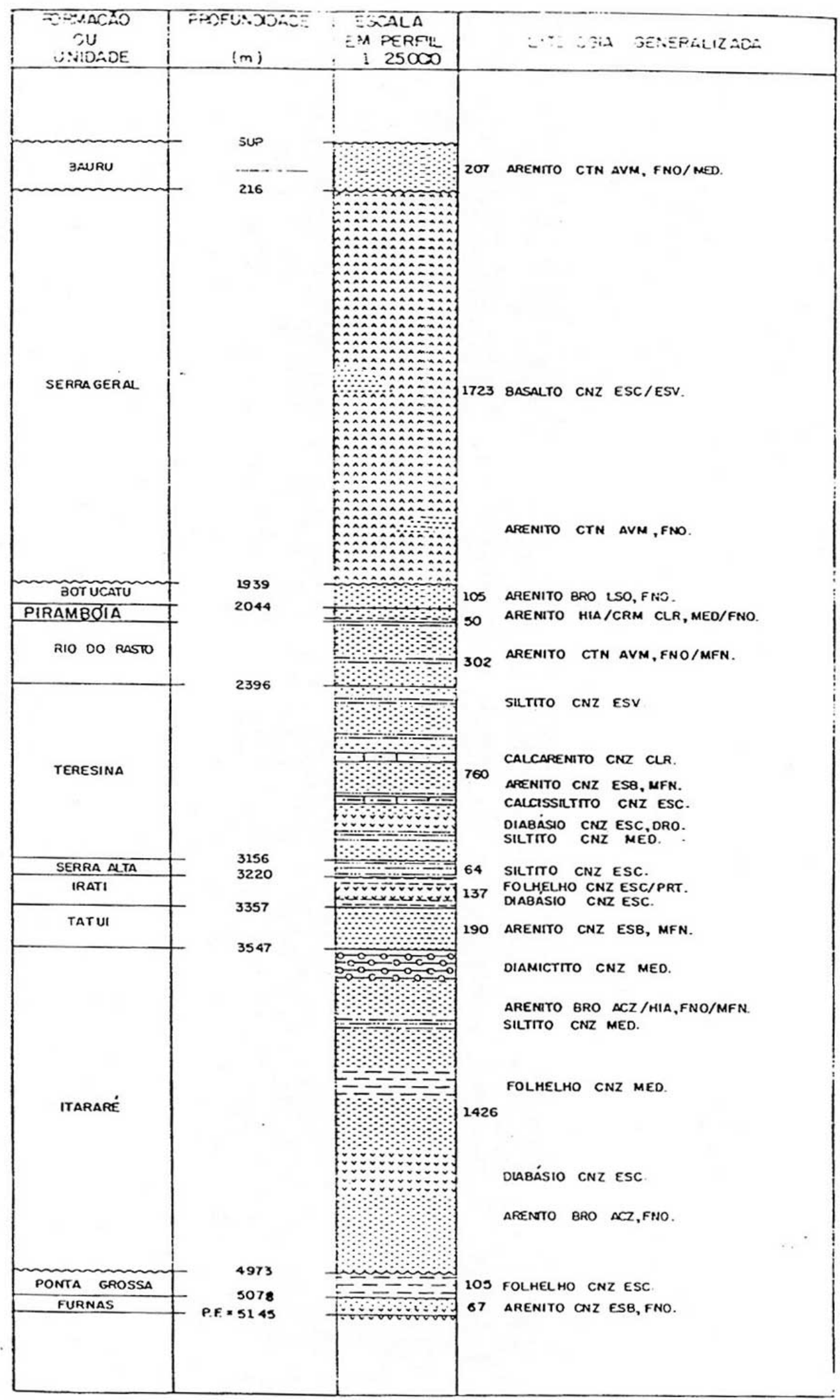

Figura 18 - Litoestratigráfia constatada no Poço 2-CB-1 - Cuiabá Paulista - SP Fonte: Consórcio CESP/IPT - Relatório do Poço Estratigráfico de Cuiabá Paulista. São Paulo. 1982 


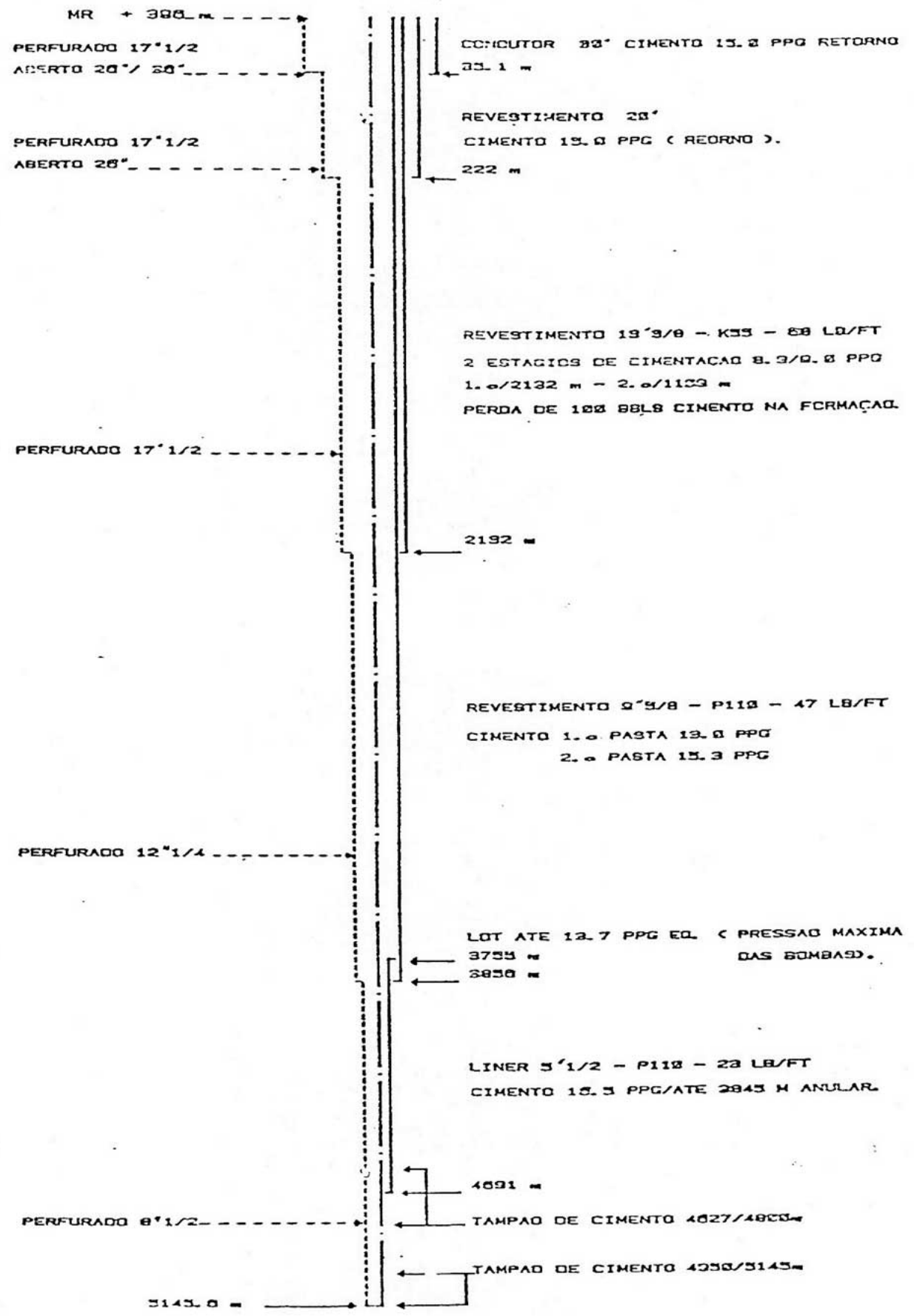

Figura 19 - Esquema de perfuração do Poço 2-CB-1 - Cuiabá Paulista - SP Fonte: Consórcio CESP/IPT - Relatório do Poço Estratigráfico de Cuiabá Paulista. São Paulo. 1982. 


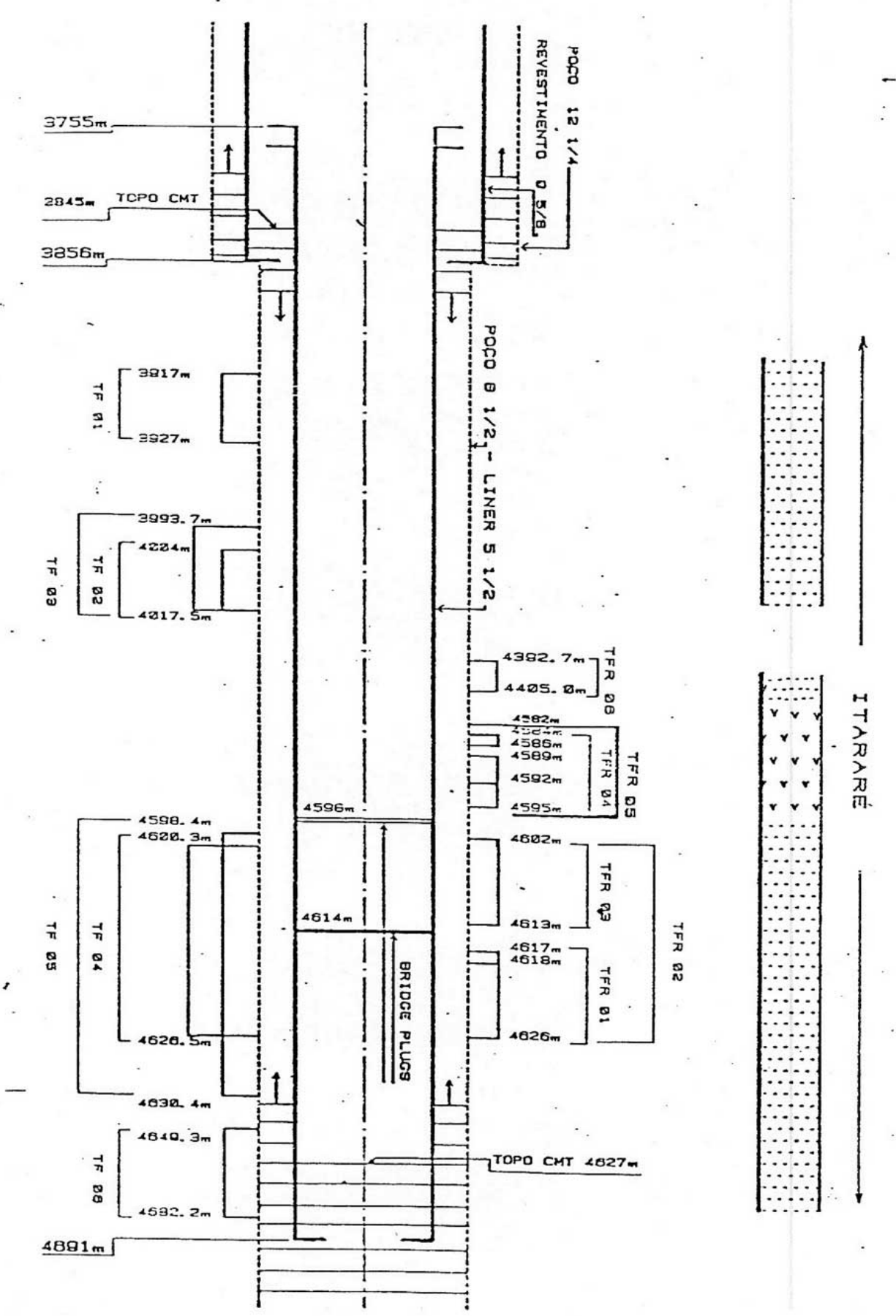

Figura 20 - Posicionamento esquemático dos testes do Poço 2-CB-1 - Cuiabá Paulista - SP Fonte: Consórcio CESP/IPT - Relatório do Poço Estratigráfico de Cuiabá Paulista. São Paulo. 1982. 


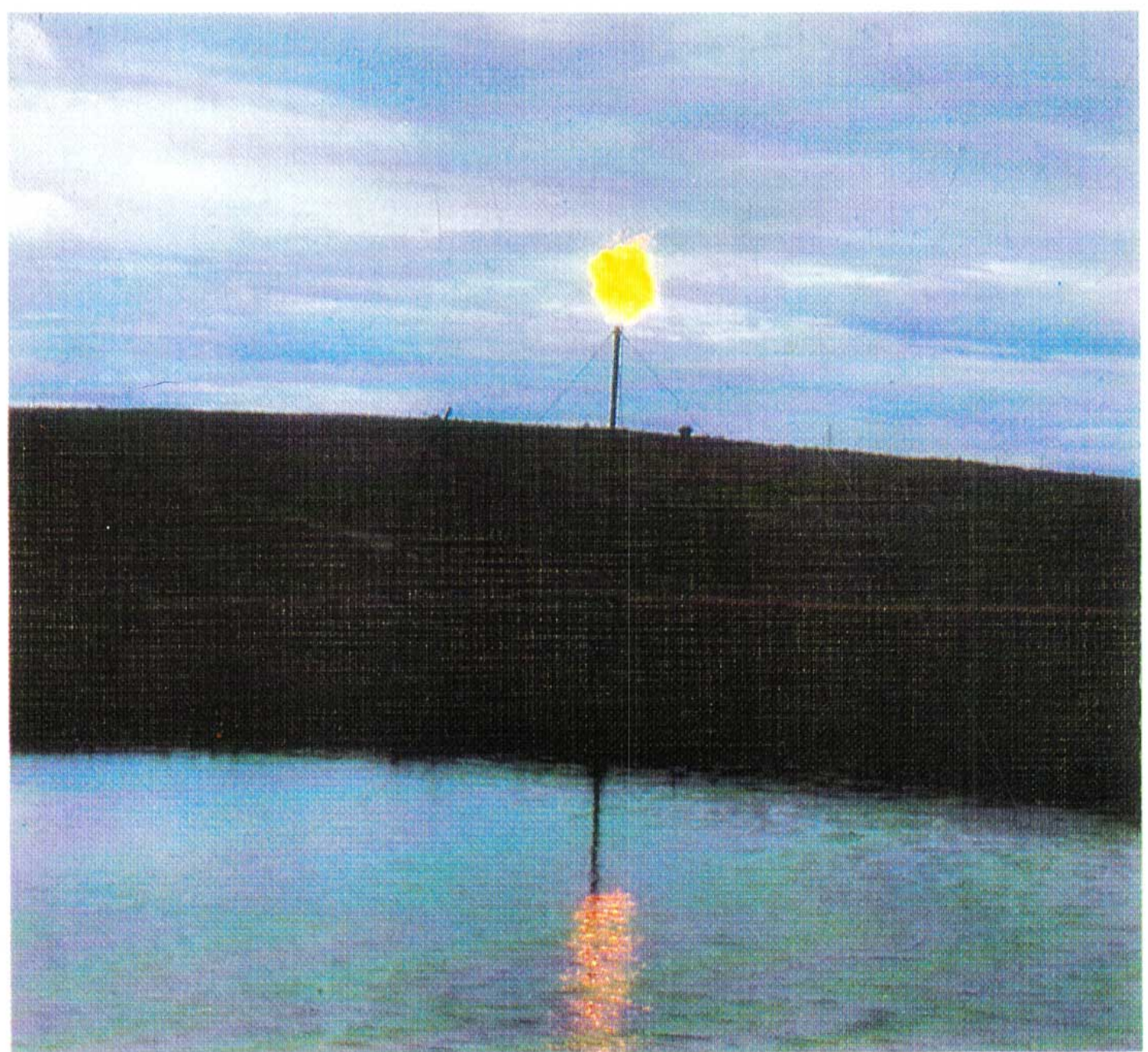

Figura 21 - Teste de formação do Poço 2-CB-1 - Cuiabá Paulista - SP Fonte: Consórcio CESP/IPT - "Relatório de Atividades" - São Paulo. 1979/1981 
"O grupo de especialistas do Consórcio CESP/IPT, encarregado da análise e interpretação de dados de bacia, após apreciar os resultados do Poço 2 -CB-1-SP de Cuiabá Paulista fez as seguintes recomendações:

1) "Efetuar testes de produção, na secção arenosa basal Formação Itararé, após fraturamento, também nos poços de Tarabaí (1 TI - 1 - SP), embora situado, fora do "trend" principal e Chapéu do Sol $(2-C S-1-P R$ e $1-C S-2-P R)$.

2) Nos casos de se conseguir produção nos testes acima, proceder à abertura dos poços $1-C A-1-P R, 1-R O-1-P R, 2-$ RP -1 - PR e outros poços a serem escolhidos em cima do "trend" -de gás e realizar testes semelhantes.

3) Pesquisar adequadamente a extensão do postulado "trend"de-gás." (CONSÓRCIO, 1982b).

O referido grupo de especialistas concluiu que a descoberta de Cuiabá Paulista, veio demonstrar alguns conceitos cuja importância, na avaliação da Bacia do Paraná, transcende ao fato em si.

O principal, sem dúvida, foi comprovar que a geração e migração de hidrocarbonetos na bacia foi tardia ou, especificamente, pós-Jurássico, o que vale dizer, após a estruturação associada ao magmatismo. Em termo de potencialidade, significa que todas as estruturas da bacia formadas até 0 Jurássico apresentam adequada relação temporal com a geração e migração de hidrocarbonetos.

Todavia, possivelmente um dos aspectos de maior relevância demonstrado pelo Poço de Cuiabá Paulista foi a caracterização de um espesso pacote arenoso de $374 \mathrm{~m}$ de espessura na base da Formação Itararé, como 
reservatório, que teria produzido $51.000 \mathrm{~m} 3 /$ dia de gás, a partir de fraturas préexistentes, uma vez que a sua elevada compactação teria diminuído sensivelmente sua porosidade. Esta hipótese que constitui mais uma indagação, mereceria atenção futura em vista do porte e natureza do reservatório encontrado no meio da Bacia do Paraná. 


\section{CONSIDERAÇÕES FINAIS}

O Programa Exploratório desenvolvido pelo Consórcio CEP/IPT alcançou diversos resultados de relevância, tanto do ponto de vista metodológico quanto do conhecimento da Bacia do Paraná, diretamente relacionado à sua potencialidade em hidrocarbonetos.

"Entre os resultados considerados relevantes, vale destacar os seguintes:

1. Nova visão estratigráfica da sedimentação paleozóica da Bacia do Paraná.

2. Além da comprovação das Formações Ponta Grossa e Irati como as principais geradoras da Bacia, em condição apropriada de maturidade, teor de carbono orgânico e natureza da matéria orgânica foi comprovada a geração tardia de hidrocarbonetos.

3. Demonstração da existência de estruturação adequada e acumulação de hidrocarbonetos na bacia.

4. Aplicação comprovada dos métodos sísmicos de reflexão em áreas com coberturas da ordem de $1.700 \mathrm{~m}$ de espessura de basalto, mostrando boa penetração, com bons refletores primários até a proximidade do nível de 2,5 segundos, correspondendo ao topo do embasamento a aproximadamente $6.000 \mathrm{~m}$ de profundidade.

5. Aplicabilidade da aeromagnetometria, que permitiu o reconhecimento de janelas do basalto, e os grandes alinhamentos estruturais da bacia. 
6. Aplicabilidade do mapeamento geológico em áreas cobertas de basalto. Até então, áreas do basalto não tinham sido objetos de mapeamento sistemático.

7. Aplicabilidade do método de Sondagens Magnetotelúricas utilizado no Programa de Exploração, em caráter experimental e pioneiro no Brasil. Os resultados técnicos obtidos pelo método através da execução de 750 estações, demonstraram sua importância, contribuindo para a confirmação de interpretações de levantamentos aeromagnetométricos e dos estudos estruturais resultantes da aplicação dos métodos de sensoriamento remoto."(YOSHIDA e GAMA JR., 1982).

O Quadro 3 apresenta os Poços do Consórcio CESP/IPT que produziram gás natural (CONSÓRCIO, 1982a).

Considerando os dados mostrados no Quadro 3, uma análise das características geológicas encontradas para a coluna estratigráfica da Bacia do Paraná, particularmente no que se refere à geração, migração e reservação de petróleo revela peculiaridades excepcionais que podem caracterizar situações chamadas "não convencionais" de seu potencial. Consideram-se "não convencionais" porque independem da existência de "trapas" tradicionalmente conhecidas de acumulação de hidrocarbonetos.

Neste caso, o gás se encontra saturando rochas de elevada dureza, compactas (arenitos compactos) e por vezes de baixa permeabilidade (folhelhos e camadas de carvão). Alguns poços que apresentaram mais de 1000 m contínuos de emanações ("shows") de gás e óleo, numa eventual reinterpretação, poderiam ser considerados à luz dos conhecimentos acerca de prospectos "não convencionais". 


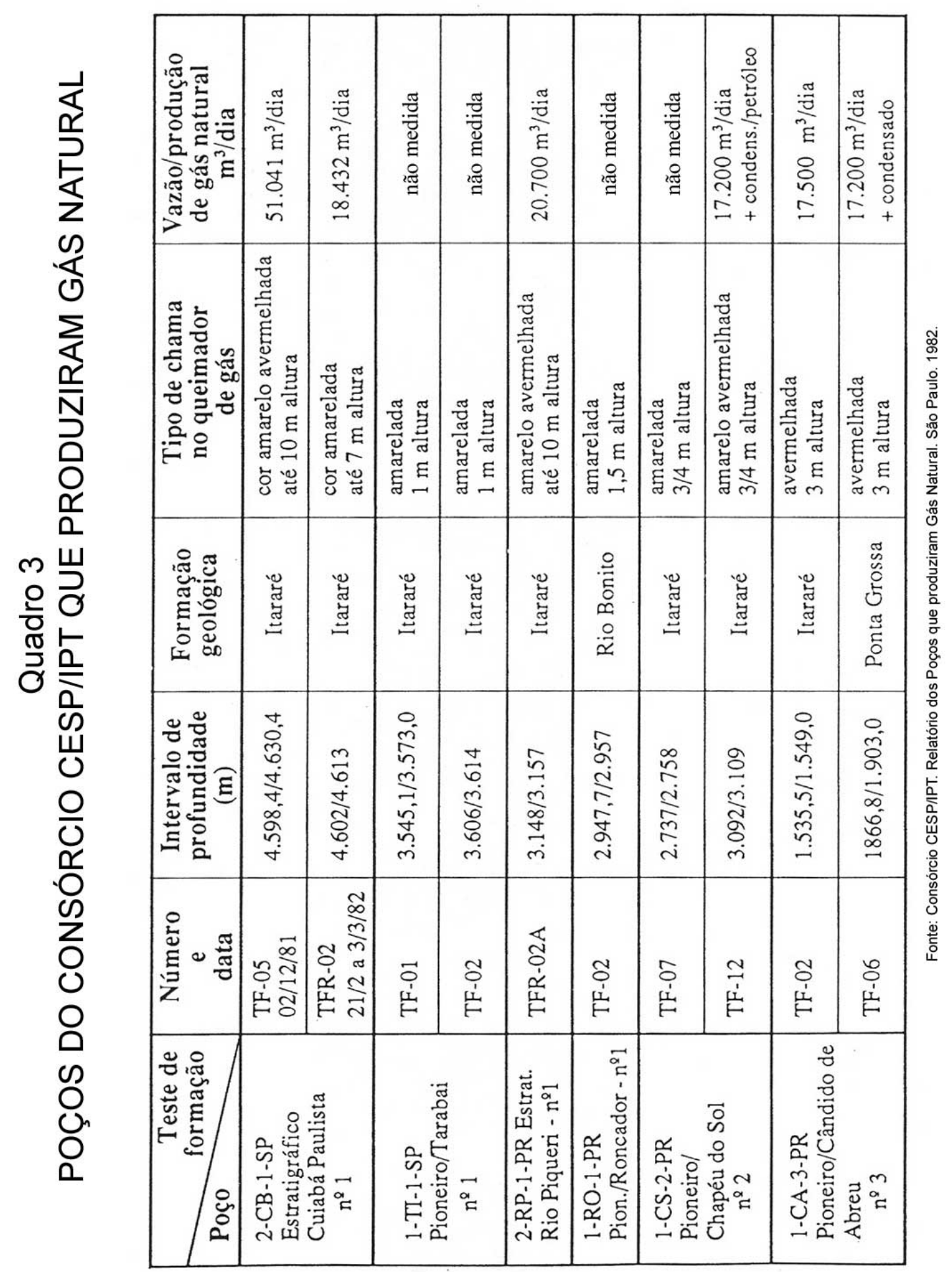


Estes aspectos contribuiriam para um novo enfoque no desenvolvimento de estratégia exploratória que no futuro poderia ser considerada para a Bacia do Paraná e às demais bacias paleozóicas do Brasil, a exemplo das grandes bacias paleozóicas produtoras, "não convencionais", dos Estados Unidos, Canadá e Rússia.

"Poços produtores em bacias paleozóicas desses países localizados em estruturas não convencionais, entraram em produção, por meio de processos de estimulação, como ,por exemplo, o fraturamento hidráulico de arenitos compactos e de folhelhos." (TIGHT, 1987).

Os Poços de Chapéu do Sol e Cândido de Abreu (no Paraná) e Cuiabá Paulista (em São Paulo) são exemplos que poderiam ser considerados. 


\section{ENCERRAMENTO DO CONSÓRCIO CESP/IPT}

A partir de abril de 1983, o Governo do Estado de São Paulo decidiu encerrar as atividades de pesquisa de hidrocarbonetos na Bacia do Paraná, determinando a desconstituição do Consórcio CESP/IPT. Os contratos de risco foram encerrados e os blocos que estavam sob concessão do Consórcio, foram devolvidos à Petrobrás. 


\section{CONCLUSÃO}

Os dados apresentados pelo Consórcio CESP/IPT após o Programa de Exploração, executado em praticamente três anos de trabalho (1980, 1981, 1982), mostraram que os resultados obtidos, nas várias áreas como geologia, geofísica, geoquímica e engenharia de perfuração, e com as inovações praticadas, juntamente com os resultados do Poço Cuiabá Paulista, proporcionaram uma reavaliação da potencialidade e prospectividade da Bacia do Paraná.

No que concerne à geofísica, após o reprocessamento dos dados sísmicos obtidos anteriormente pela Petrobrás, utilizando-se de softwares avançados, obtendo resolução de melhor qualidade, o Consórcio CESP/IPT contratou seis equipes para trabalhar com reflexão sísmica, obtendo $75 \%$ de dados que efetivamente foram utilizáveis na localização de áreas com característica favoráveis à acumulação de hidrocarbonetos, o que mostrou que a prospecção sísmica de reflexão funciona para a Bacia Geológica do Paraná, derrubando um paradigma que existia antes do consórcio.

Quanto à geoquímica, estudos de avaliação das Formações Ponta Grossa e Irati, realizados nos Laboratórios de Ensaios e Análises do Consórcio CESP/IPT, com amostras de material de poços perfurados pelo consórcio e de materiais de poços perfurados anteriormente pela Petrobrás, em áreas de concessão do Consórcio, mostraram a geração de hidrocarbonetos em suas áreas estudadas.

Em relação à engenharia de perfuração, os resultados obtidos pelo Consórcio CESP/IPT, no programa executado pela perfuração de 32 poços: 
- Nenhum poço foi interrompido ou perdido, chegando todos ao final da perfuração conforme proposto;

- Foi desenvolvido programa eficaz de otimização, na utilização de brocas;

- Foi testada e aprovada a utilização de perfuração a ar (Air Drilling), principalmente para as formações basálticas, que retardavam as perfurações (experiência pioneira na Bacia do Paraná).

Esses resultados mostraram que os objetivos da engenharia de perfuração foram alcançados. 


\section{REFERÊNCIAS}

CONSÓRCIO CESP/IPT - "Relatório de Atividades 1979/1981" - São Paulo, 1981.

CONSÓRCIO CESP/IPT - "Manual do Supervisor de Perfuração" - São Paulo, 1981a. (Relatório Interno).

CONSÓRCIO CESP/IPT - "Principais Fases da Operação de Sonda" - São Paulo, 1981b. (Relatório Interno).

CONSÓRCIO CESP/IPT - Relatório de Materiais - "Programa de Brocas" São Paulo, 1981c. (Relatório Interno).

CONSÓRCIO CESP/IPT - "Geologia da Bacia do Paraná. Reavaliação da Potencialidade e Prospectividade em Hidrocarbonetos" - São Paulo, 1982.

CONSÓRCIO CESP/IPT. Relatório de Poços que Produziram Gás Natural. São Paulo, 1982a. (Relatório Interno).

CONSÓRCIO CESP/IPT - "Relatório do Poço Estratigráfico de Cuiabá Paulista" - São Paulo, 1982b. (Relatório Interno).

CONSÓRCIO CESP/IPT - "Relatórios de Perfilagem e Testes de Formação" São Paulo, 1982c. (Relatórios Internos - Agrupamento de Subsuperfícies). 
GALHANO, F. A. P.; HENNIES, W. T.; STELLIN JUNIOR, A.; VIANNA, R. B. Reflection Seismic in Paraná Basin. In: International Symposium on Mining Planning and Equipment Selection; Torino, Italy, 2006. Mine Planning and Equipment Selection 2006: Proceedings. M. Cardu, R. Ciccu, E. Lovera, E. Michelotti, 2006. V.1. P.555-560. 2006a.

GALHANO, F. A. P.; LAUAND, V. H.; HENNIES, W.T.;MONTEIRO, J.R.C.; The drill bit Program in oil exploration at the Paraná Basin. In: International Symposium on Mining Planning and Equipment Selection; Torino, Italy, 2006. Mine Planning and Equipment Selection 2006: Proceedings. M. Cardu, R. Ciccu, E. Lovera, E. Michelotti, 2006. V.2. P.1249-1254. 2006b.

GOULART, E.P.; JARDIM, N.S.. Avaliação Geoquímica das Formações Ponta Grossa e Irati - Bacia do Paraná. In: Consórcio CESP/IPT. Geologia da Bacia do Paraná. Reavaliação da Potenciabilidade e Prospectividade em Hidriocarbonetos. São Paulo, 1982.

Instituto de Pesquisas Tecnológicas do Estado de São Paulo (IPT) - "Programa de Estudos Geológicos na Bacia do Paraná no Estado de São Paulo" - São Paulo, 1979.

LEAL FILHO, L.S.; LONGO, E.G.; STELLIN JR, A; HENNIES, W.T. Detection and control of pollutant plumes by resistivity measurements. In: International Symposium on Mining Planning and Equipment Selection, 5.; São Paulo. 1996. 
Mine Planning and Equipment Selection 1996: Proceedings. Rotterdam, Balkema, 1996. P. 239-244.

SILVA, G.R., VIANNA, R.B. Aplicabilidade do Método de Reflexão Sísmica na Bacia do Paraná. In: Consórcio CESP/IPT. Geologia da Bacia do Paraná. Reavaliação da Potencialidade e Prospectividade em Hidrocarbonetos. São Paulo 1982.

SIMON, F.M.; ROLA, J.G.R.; BRUNO, J.A. Avaliação de Formações na Bacia do Paraná. In: Consórcio CESP/IPT. Geologia da Bacia do Paraná Reavaliação da Potencialidade e Prospectividade em Hidrocarbonetos. São Paulo. 1982.

TIGHT gas sands R \& D: mastering methods for improved gas production. In Grid - Gás Research Industrial Digest., 1987. p. 2-9. (Summer).

YOSHIDA, R, GAMA JR., E. Introdução In: Consórcio CESP/IPT. Geologia da Bacia do Paraná. Reavaliação da Potencialidade e Prospectividade em Hidrocarbonetos. São Paulo. 1982. 


\section{REFERÊNCIAS COMPLEMENTARES}

BAUMANN, P - Petroleum Evaluation of Paraná Basin. São Paulo. Consórcio CESP/IPT e BEICIP, 1981. V.3 (Relatório RT 033/81).

GO-GEARHARTOWEN WIRELINE SERVICES - Formation Evaluation Data Handbook, Fort Worth, Texas, 1978. - 240 p.

HALLIBURTON SERVICES - Drill Stem Testing and Special Tools Technical Literature. Oklaloma, 1980. (Catalog of Course).

LESKINEN, R.E. Introduction to Seismic Processing. Houston. s. ed. 173p. 1975.

SCHLUMBERGER - Log Interpretation. V.1. - Principles. New York, 1972. 112 p.

SCHLUMBERGER - Log Interpretation. V. 2. - Applications. New York, 1974. $116 \mathrm{p}$.

SCHLUMBERGER - Log Interpretation Charts. New York, 1978. 97 p.

SILVA, G.R. High Resolution Seismic Application in Sergipe Basin and Possibility in Petroleum Prospection. In: Annual Offshore Technology 
Conference, 11, Texas. 1979. Proceedings. Texas, OTC. V. 4, p. $2281-2291$ (Paper OTC 3620).

VIANNA, R.B., OLIVEIRA, G., MORAES, R.A., OHOFUGI, W. COVA, N. Metodologia do Consórcio CESP/IPT para prospecção geofísica na Bacia do Paraná.In: Seminário sobre Exploração de Petróleo no Brasil (SEMPET) Rio de Janeiro, 1981. Programas com Resumos. Rio de Janeiro. PETROBRÁS. p. 16. 